\title{
NOTAS DE VARIA LECCIÓN A LA ARCADIA DE LOPE DE VEGA
}

\author{
IgnACio Arellano \\ Universidad de Navarra - GRISO \\ iarellano@unav.es
}

1. La eRUdición de La ARCADIA Y LAS fUentes de Lope. El PAPEL de LAS MISCELÁNEAS Y POLIANTEAS

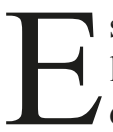

s lugar común en la crítica la afición de Lope a componentes eruditos, de la cultura y la literatura clásica, y a todo tipo de noticias enciclopédicas de botánica, zoología, astronomía y otras materias que inserta en sus obras, como es el caso de la Arcadia, afición que ha recibido a menudo valoraciones negativas. Morby señala, por ejemplo, que «Lo que más desfavorablemente se ha criticado en la Arcadia ha sido su pedantería. Al que no conoce sino la Diana de Montemayor puede sorprenderle el lastre erudito...» (1975: 17). Morby justifica - poco verosímilmente- ese «lastre erudito» del relato pastoril atribuyendo a Lope un deseo de renovación educativa que contraste con la propensión del género a los «cuentos y novelas» (1975: 18), aunque no lo cree del todo exitoso debido a que los «rellenos» — fábulas, anécdotas o academias - resultan «harto menos estructurales que las aventuras paralelas eliminadas» (1975: 19). Otros, como Avalle Arce (1959: 139) denuncian la estructura caótica de la obra y la supuestamente ingenua pretensión de cultura del Fénix por su recurso a las polianteas de la época, que Morby también resalta («fácil arbitrio de los prontuarios» [1975: 31]), y que señalan muchos estudiosos, especialmente la Officina de Ravisio Textor, el Compendium naturalis philosopiae... de Titelmans, el Dictionarum historicum, geograficum, poeticum de Carolus Stephanus o Il sapere util'e delettevole de Constantino Castriota $^{1}$. Algunos, en fin, como Sánchez Jiménez (2012), se esfuerzan en

\footnotetext{
1 Ver, entre otros, Conde Parrado y García Rodríguez (2002), Egido (1990), González Barrera (2007), Jameson (1937), Morby (1967; 1968), Osuna (1968; 1996), Trueblood (1958) y Vosters
}

Edad de Oro, XL (2021), pp. 387-425, ISSN: 0212-0429 - ISSNe: 2605-3314

DOI: https://doi.org/10.15366/edadoro2021.40.020 
advertir en la Arcadia una peculiar coherencia y originalidad, entre cuyos aspectos se contaría precisamente la erudición, manifestada en las listas de virtudes de animales y plantas, o en la «Exposición» final a modo de comentario docto $^{2}$. La mayoría de los críticos abordan la cuestión de si las informaciones de Lope son de primera mano o provienen de fuentes secundarias por una labor de empeñoso acarreo que de algún modo devaluaría el exhibicionismo de la cultura lopiana.

Creo que conviene replantear el asunto examinando dos aspectos: por un lado, los mecanismos y límites que definen la inserción de estos elementos; por otro, la función que desempeñan en una obra como la Arcadia. A menudo se busca un repertorio como el de Ravisio Textor - uno de los favoritos de Lope, sin duda, como estudian Conde Parrado y García Rodríguez, Egido, González Barrera, Morby, Trueblood, etc.— para identificar una «fuente». Sánchez Jimé$n^{3} z^{3}$ parece concebir a Lope escribiendo la Arcadia con el repertorio de Textor al lado, en el que va buscando información a cada paso, pero aunque sea bien conocido este uso que hace el poeta de la Officina no es necesario pensar que recurra a ella para muchas curiosidades que menciona, porque numerosos motivos están demasiado extendidos, de manera que hay que analizar con cuidado los requisitos que denuncian una fuente concreta de inspiración; en muchas ocasiones será imposible determinar cuál es esa fuente, que bien puede no existir como un texto concreto. Algunos casos significativos pueden ser buenos ejemplos de lo que apunto.

Para la «anfesibena»- - «monstruosa sierpe que tiene otra cabeza en la cola» (Vega, 2012: 246) — anota el citado estudioso que «Lope encontró el nombre y descripción de la anfesibena en Ravisius Textor» (Vega, 2012: n. 221)4. Pero no es tan seguro. Textor mismo indica su fuente en Plinio (VIII, 23: «La anfisbena tiene dos cabezas, la una donde las demás, y la otra en la cola»); la mencionan también Solino en De las cosas maravillosas del mundo («La anfisbena tiene dos cabezas, una de las cuales tiene en la parte delantera y la otra tiene en la cola», f. 81v); y la comentan Eliano, Lucano, san Isidoro, Dante, Ercilla, Pulci, Boiardo, el anónimo Baldo, etc. ${ }^{5}$. No es posible saber de dónde saca Lope su información; es

(1962; 1975). Para más referencias sobre este asunto, ver la lista bibliográfica de la nota 1 de González Barrera (2007).

2 Exposición a modo de diccionario de motivos que saca Lope del Dictionarium de Carolus Stephanus precisamente. Ver Osuna (1968).

3 Constantemente señala que tal o cual motivo lo encontró o pudo encontrarlo Lope en Textor, pero en muchos de esos casos Lope lo pudo sacar de cualquier lado.

4 Textor: «Geminum caput habet Amphisibena, hoc est, ad caput et ad caudam tanquam parum esset uno ore fundit venenum, inquit Plinius...».

5 Eliano, Historia de los animales, libro IX, 23; Lucano, Farsalia, libro 9, v. 719; san Isidoro, Etimologías, 12, 4, 20: «Ampisbaena dicta, eo quod duo capita habeant, unum in loco suo, alterum 
más que probable que ni él supiera decir en qué momento conoce la anfisbena ni en qué fuente - muchos de los textos citados debió de conocerlos Lope bastante bien- bebió tal información. En un caso como este, la extensión del motivo lo constituye en mostrenco y dificulta mucho, si no hay otros rasgos que fijen una fuente concreta, decidir de dónde proviene.

Lo mismo puede decirse de los cinco triunfos del César (Vega, 2012: 397), noticia de la que el mismo anotador señala que «la pudo haber encontrado Lope en Ravisius Textor» (n. 538). Podría ser, pero la noticia proviene de Suetonio (2006: 37) y de ahí se extiende para servir de inspiración a numerosas representaciones renacentistas (Sebastián, 1981). Lope, en suma, no necesita acudir a Textor para este detalle. Que la triaca se fabrica con veneno de la víbora es detalle corriente (Vega, 2012: 538), pero, en este caso, la inserción en una serie de datos que provienen indudablemente de Castriota (Morby, 1975: 343) justifica la relación apuntada con dicho repertorio. Otras veces, un detalle revela que la fuente no es el frecuentado Ravisio Textor. «Cinco días le pedí / a Nino para reinar» dice Semíramis (399), dato que no cuadra a Sánchez Jiménez, quien anota que «Según la versión de Ravisius Textor que sigue Lope [...] Semíramis solo le pidió un día a su marido Nino». Pero Lope, en realidad, no sigue a Textor y la fuente última de este dato no es la Officina sino la Biblioteca histórica de Diodoro Sículo:

después se convirtió en esposa legal, se le pidió al rey a ceder el imperio durante cinco días. Después de haber recubierto luego con el cetro y el manto real, Semíramis utilizó el primer día para dar magníficas fiestas, a la que se invitó a los jefes del ejército y de las personas más importantes del estado de poner sus intereses. En el segundo día, en que los pueblos y grandes le rindieron homenaje en la reina de la calidad, se echó a su marido en la cárcel; y como ella se hizo de forma natural para las grandes empresas y llena de audacia, ella agarró el imperio [...] (II, 20).

Lope pudo tomarlo también a través de la tragedia de Virués, La gran Semíramis:

in cauda»; Dante, Inferno, canto 24, vv. 85-87: «Più non si vanti Libia con sua rena; / ché se chelidri, iaculi e faree / produce, e cencri con anfisibena»; Ercilla: «También en otra parte parecía / la coyuntura de la dura hiena, / y el meollo del cencris, que se cría / dentro de Libia en la caliente arena / y un pedazo del ala de una harpía, / la hiel de la biforme anfisibena» (Araucana, CORDE); Baldo anónimo: «No faltaban allí tostadas dípsades y la pesada anfisibena de dos cabezas» (CORDE); Pulci, Morgante, XXV, 322-331: «Disse Astarotte: —La gran Libia mena / molti animali incogniti alle genti, / de'quali alcun si dice anfisibena, / e innanzi e indrieto van questi serpenti / che in mezzo di due capi hanno la schiena; / altri in bocca hanno tre filar di denti, / con volto d'uom, manticore appellati; / poi son pegàsi cornuti ed alati»; Boiardo, soneto «De qual sangue Lernéo fu tinto il strale, / Di qual fiel di cieraste o anfisibena, / Il stral, che il cor mi punge in tanta pena, / Che altra nel mondo a quella non è equale?», etc. 
Pídeme que le dé por cinco días el gobierno de todos mis estados, dejando yo todas las veces mías, toda mi potestad y mis cuidados

(vv. 829-832).

\section{$[\ldots]$}

Con ecesivo amor, gozo y contento de su mano el gran Nino aquí os corona, y os doy, como pedís, por cinco días, todo el gobierno de las tierras mías

(vv. 858-860).

Dicho de otro modo, no siempre Lope habrá consultado un repertorio determinado para todos estos elementos de erudición curiosa propios de las silvas de varia lección. La insistencia de los anotadores en localizar motivos en Ravisio Textor, por ejemplo, no responde a la técnica que yo creo más verosímil: pues muchos motivos pertenecen ya a una cultura común, están diseminados por todas partes y, precisamente, la afición de Lope a esta clase de material hace que se integren en la Arcadia de manera directa, sin mediación necesaria de un determinado repertorio, cuya presencia — sin duda muy acusada - deberá hacerse evidente en la acumulación, orden de las citas o adaptación indiscutible de una fórmula: tal es el caso de Castriota, cuyo libro Il sapere util'e delettevole ha sido explotado sistemáticamente por Lope, como estudió Edwin S. Morby (1968).

Hay dos pasajes, el repertorio de flores de comienzo del libro primero (Vega, 2012: 176-178) y el discurso de Anfriso sobre virtudes de plantas, animales y piedras (Vega, 2012: 537-541) que constituyen un «mosaic of fragments painstakingly selected from Castriota's repertory» (Morby, 1968: 203). La presencia de Castriota en estos pasajes es nítida: la serie de elementos, su ordenación, los rasgos que se les atribuyen, etc. demuestran la explotación prácticamente de todo el libro de Castriota, con algunas supresiones (el adonio, la amapola o el loto en la primera lista) y algunos rasgos añadidos y en general con una reducción a los elementos básicos (las cinco páginas del discurso de Anfriso recorren prácticamente todo el volumen del italiano).

En este caso, el estrecho ceñimiento a la fuente permite aclarar algunas menciones. Sánchez Jiménez, al anotar el lino indiano resistente al fuego (Vega, 2012: 177), confiesa desconocer de dónde extrajo Lope «la información sobre el lino indiano, hierba que resiste el fuego» (Vega, 2012: n. 64). Pues la pudo extraer sencillamente de Plinio (1999: XIX) ${ }^{6}$, que es la fuente de Castriota, pero dada la inspiración de

6 «Y se ha hallado lino a quien no consume el fuego, que llaman vivo [...]. Nacen en los lugares desiertos y abrasados con el sol de la India [...] y acostumbra a vivir ardiendo»; versión latina: «Inventum iam est etiam quod ignibus non absumeretur. vivum id vocant, ardentesque in focis 
todo el pasaje, es seguro que en esta ocasión Lope saca su referencia del mismo Il sapere util'e delettevole: «Son di lui [del lino] più le spetie e fra l'altre una si trova in India, che resiste al fuoco, et è vivo» (f. 72r). Muchos otros textos hablan del «lino asbestino», tela que se supone se tejía del asbesto mineral, resistente al fuego ${ }^{7}$, y que parece variante contaminada con este otro lino herbáceo.

Pero, yendo a la segunda cuestión suscitada arriba, ¿qué objetivos tiene este tipo de acumulaciones eruditas y curiosas de varia lección? ¿Es, como se ha dicho a menudo, una exhibición algo trivial de unos conocimientos que Lope no había adquirido de primera mano?

Creo que en la sátira del prólogo del Quijote, que parece enderezada contra Lope, Cervantes intuye con precisión el uso que hace el Fénix de estos materiales, aunque lo juzgue negativamente. En palabras de Conde Parrado y García Rodríguez:

parece claro que lo que Cervantes critica, como se demuestra en los consejos que, más adelante en el mismo prólogo, le brindará el anónimo amigo, es que dicho empleo se convierta más en un fin que en un medio, cuando se recurre de manera caprichosa y acrítica a esos «librotes» (2002: 3 ).

Pero si no yerro, sucede que Lope pretende ese objetivo y trata estos elementos curiosos como un fin en sí mismos; es decir, en el texto de la Arcadia (en otros hay variantes de uso y funciones) la carga erudita constituye un repertorio de curiosidades que pretenden interesar al lector por los mismos motivos que pudieron interesarle libros como las polianteas manejadas o las silvas de varia lección como la famosa de Pero Mexía o el Jardín de flores curiosas de Torquemada. A mi juicio, Lope no quiere «dignificar» con «ingredientes culturales y pedagógicos» un relato de entretenimiento e imaginación — como proponía Morby (1975) - sino que actúa en parte como un compilador más de curiosidades, no como mero receptor de informaciones de colectáneas de varia lección. Es una diferencia que me parece significativa para concebir el modo de composición del libro. De cualquier manera, no intento ahora abordar un análisis de la estructura de la Arcadia y en qué proporción aparece el material de misceláneas o silvas curiosas; me limitaré, muy modestamente, a proponer algunas explicaciones para ciertos motivos que a mi juicio requieren alguna explanación para ser comprendidos por un lector hodierno, y que los anotadores precedentes no han apurado del todo ${ }^{8}$.

conviviorum ex eo vidimus mappas sordibus exustis splendescentes igni magis quam possent aquis. regum inde funebres tunicae corporis favillam ab reliquo separant cinere. nascitur in desertis adustisque sole Indiae, ubi non cadunt imbres, inter diras serpentes, adsuescitque vivere ardendo». Ver Arellano (2015: 48-49) para otra documentación del lino asbestino.

8 Mi referencia será la edición de Sánchez Jiménez, la más reciente y abundante en notas y que incorpora generalmente las informaciones de Morby. 
Esta acumulación erudita - désele la interpretación que fuere- plantea en efecto, grandes dificultades al lector y editor modernos. Las ediciones que podemos tomar en consideración para la Arcadia son las de Morby (1975) y Sánchez Jiménez (2012). Morby utilizó para sus notas la «Exposición» final que no incluye en su propia edición, y que explota como fuente principal de informaciones, adaptando sus definiciones a menudo, pero su tarea es mucho menos elaborada que la que realizó para la Dorotea (1980), dejando en la Arcadia demasiados lugares sin dilucidar. La edición de Cátedra ofrece un aparato de más de 1.200 notas, pero en ellas abundan las estrictamente literales (sacadas a veces de la «Exposición», sin elaboración contextual), y se inclina excesivamente a proponer a Ravisio Textor como fuente de muchos motivos sin suficiente justificación, lo que le impide apurar otras posibilidades que a menudo aclaran supuestas confusiones de Lope, y siguen pendientes de explicación muchos pasajes.

Cierto que anotar exhaustivamente y con total eficacia un texto como la $\mathrm{Ar}$ cadia es complicado, de manera que nada de extraño tiene que la tarea presente siempre posibles refinamientos y complementos, que es el objetivo (parcial) que pretendo con estas notas de varia lección, atinentes a unos cuantos lugares de la obra de Lope que me parecen todavía necesitados de glosa.

\section{LA CULEBRA Y LA MURENA}

Galafrón, en una serie de ejemplos de amores que contrapone a los desdenes de ciertas amadas, menciona a tigres y serpientes, hiedras y olmos, víboras y áspides, y entre ellos el ejemplo de la culebra y la murena: «a la culebra la murena siente» (Vega, 2012: 196), que en la edición de Morby (1975: 81) pasa sin nota y en la de 2012 se solventa con una nota literal («Murena: morena»), que no aclara el motivo zoológico aludido, el cual es un clásico de los repertorios, y que conviene explicar para entender también el uso del verbo «sentir» (la murena «siente» a la culebra) en el pasaje antecitado.

Se refiere el texto a los amores o cópula de la murena y la víbora o culebra, que comenta ya Plinio: «Dicen que se ayunta la víbora con la murena y la llama y solicita con silbos desde la ribera, y en sintiendo que viene, para no causarla daño, vomita el veneno que tiene» (cit. por CORDE). Claudio Eliano le dedica un capitulillo del libro I de su Historia de los animales, a este apareamiento de la murena y la víbora:

Cuando la murena se llena de frenesí genesíaco, se dirige a tierra y desea ardientemente el trato con un macho, aunque sea un macho muy perverso, pues se acerca a la madriguera de una víbora y ambos se aparean. Dicen también que la víbora, aguijoneada por la lujuria, se llega hasta el mar para realizar la cópula, y al igual que un juerguista golpea con su flauta la puerta, así la víbora llama con silbidos a la 
amada y esta sale. De modo que la Naturaleza hace que seres que viven separados unos de otros se junten en un común deseo y en un lecho común (2008: I, 50).

Por eso la murena «siente» («oye» el reclamo amoroso de la culebra, los silbos con los que la llama para que se acerque a la orilla): «sentir»: 'Particularmente se toma por oír, o percibir con el sentido del oído’ (Diccionario de autoridades).

\section{Grullas, piedras y el monte Tauro}

En el canto del gigante a Crisalda se acumulan numerosos motivos bien conocidos en repertorios de curiosidades y emblemas. El primero que merece algunas palabras es el de las grullas y el monte Tauro. Alasto ofrece a Crisalda una serie de regalos y riquezas: perdices, calandrias, águilas, tórtolas, ánades... entre ellos las grullas:

la grulla muerta en las viñas no de noche cuando vela, que no soy yo el monte Tauro para pasarme con piedras

(Vega, 2012: 225).

El pasaje recibe esta nota de Sánchez Jiménez':

De las grullas se creía que «de noche, mientras duermen, y de día, en tanto que pacen, tienen sus centinelas que las avisan si viene gente» (Tesoro [...] y que para velar así sostenían una piedra con el pico, que si se dormían las despertaba con el ruido de su caída (Ravisius Textor, Officinae, vol. II, pág. 190). Alasto prefiere las grullas muertas para comer, no las que velan con piedras, pues no es un monte para poder mantenerse de rocas. El monte Tauro está al extremo del Cáucaso («Exposición»).

Varias precisiones deben hacerse antes de comprender las alusiones del pasaje, que van por otro camino del que traza la nota citada. La primera es que Textor no dice (como asegura Sánchez Jiménez) que las grullas centinelas lleven una piedra en el pico, sino que la llevan en una pata: «excubias agunt nocturnas, lapillum pede sustinentes, quia lassatis somno decidens indiligentia sono coarguat» (1593: II, 171), que es copia casi a la letra de un pasaje de Plinio. Curiosamente la piedra en el pico explica la mención del monte Tauro, pero las alusiones son algo más complicadas de lo que intuye el editor ${ }^{10}$. Me permitiré aquí una pequeña diversión sobre los pájaros y las piedras.

\footnotetext{
9 Morby (1975: 103) se limita aquí a copiar el texto de la «Exposición» sobre el monte Tauro, que resume también Sánchez Jiménez en una nota «literal» que no aclara la alusión ingeniosa.

10 Reutilizo materiales de Arellano (1990), donde trato estas historias de pájaros y piedras y recojo
} 
Plinio anota, en efecto, entre las costumbres de las grullas (1999: X, 30, 59) la de tener centinelas nocturnas que usan como despertador la piedra en la pata que el sueño relaja, avisando con el golpe: «Excubias habent nocturnis temporibus lapillum pede sustinentes qui laxatus somno et decidens indiligentiam coarguat». Otras piedras — que ahora no interesan- cogen también en las patas las grullas cuando vuelan en zonas tormentosas, añadiendo a la piedra la arena que toman en el buche, para lastrarse y sostener mejor su estabilidad (Plinio, 1999: X, 30, 60; Textor, 1593: II, 171). Tanto el lastre como la piedra para despertar centinelas dormidas pasan a las ejemplificaciones de grullas en múltiples textos desde la edad antigua hasta el XVII pasando por los bestiarios medievales.

La mención del monte Tauro viene reclamada por asociación de ideas: la mención de la grulla veladora atrae el motivo de la piedra y este, a su vez, el de otra piedra relacionada con el monte Tauro. Esta piedra se relaciona en la mayor parte de los textos con el ánsar, pero en ocasiones se les atribuye a las grullas: ánsares - o grullas - al atravesar el monte Tauro en el que acechan las águilas, toman una piedra en el pico para forzarse a guardar silencio mientras vuelan en la región ${ }^{11}$.

Plutarco, por ejemplo, en Moralia (967B), cuenta que los ánsares, con el miedo de las águilas, al cruzar el monte Tauro, toman una piedra en el pico para que les impida gritar mientras pasan. Además de Plutarco, hay dos obras antiguas, las de Eliano y Amiano Marcelino, citadas constantemente en los abundantes libros de emblemas que recogerán en lo sucesivo este motivo. En la Historia de los animales (V, 29), Claudio Eliano explica que los ánsares, cuando cruzan el monte Tauro, temen a las águilas, y cada uno, cogiendo en su pico una piedra para no hacer ruido, como quien se pone en la boca un freno, vuelan en silencio, y de esta manera, la mayoría de las veces escapan a la atención de las águilas. De Plutarco y Eliano pasan a Amiano Marcelino:

linquentes orientem ansares ob calorem plagamque petentes occiduam cum monten penetrare coeperint Taurum aquilis abundantem, timentes fortissimas uolucres, rostra lapillis occludunt, ne eis eliciat uel necessitas extrema clangorem, isdemque collibus agiliores uolatu transcursis proiciunt calculus [...] (1967: XVIII, III, 9).

De estos lugares, principalmente de Marcelino, se trasladan a la emblemática de los siglos XVI y XVII, donde se hacen lugar común, como en Juan de Horozco y

los testimonios del paso del monte Tauro por los ánsares y grullas acechados por las águilas.

11 La frecuencia del rasgo del grito en el vuelo (la grulla que sirve de guía a la formación grita siempre hasta volverse ronca [Plinio, 1999: X, 30]), y la lucha con las águilas, separan en la mayoría de los casos a las grullas de la emblematización del silencio con la piedra en el pico, que se atribuye, sobre todo, a los ánsares temerosos de las rapaces, pero la contaminación es también frecuente, de manera que las grullas con la piedra en el pico aparecen a menudo por el monte Tauro. 
Covarrubias, cuyo emblema XLI del libro III de sus Emblemas morales se dedica al silencio con el mote «Silentium vita», y un ánsar en la ilustración, volando sobre el monte Tauro con una piedra en el pico. Horozco añade una explicación poética:

\author{
Pasando el monte Tauro a su ventura \\ el ánsar bravo con temor crecido \\ del águila real, siempre procura \\ volar de suerte que no sea sentido, \\ y para su defensa más segura \\ porque no se descuide en dar graznido \\ una piedra en el pico siempre lleva \\ con que el silencio ser la vida prueba
}

(1589: III, f. 183).

Y un comentario en prosa donde menciona su fuente («estas aves que criándose muchas dondequiera, las que están de parte del monte Tauro tienen esta propiedad, y así lo cuenta Amiano Marcelino, aunque otros dicen esto de las grullas. Es el monte Tauro en la Asia», etc.). A este lugar de Horozco Covarrubias pueden añadirse muchos otros que prueban la extensión del motivo.

Piero Valeriano, en Hieroglyphica sive de sacris aegyptiorum, aliarium Gentium, pone el emblema de los ánsares con su piedra en el pico, emblema del silencio, y remite a Amiano. Las Empresas morales de Juan de Borja (1581) vuelven a representar el ave con la piedra en el pico, con el mote «Tuta Merces», y la identifica, en este caso, con la grulla. En 1599, aparecen en Madrid las Emblemas moralizadas de Hernando de Soto, en cuyo f. 22r imprime de nuevo el emblema de un ánsar sobre un monte, que lo sobrevuela con una piedra en el pico, bajo el mote «Mors et vita lingua. La muerte y la vida es la lengua».

El famoso repertorio de Cesare Ripa explica para el Silencio:

volviendo a los gansos escribe sobre ellos Ammiano que [...] viéndose en la necesidad de atravesar el monte Tauro, donde abundan enormemente las águilas, temerosos de sus pobres fuerzas y para no descubrirse y darse a conocer con el ruido de su boca, recogiendo una piedra con el pico se la llevan consigo hasta salir de la zona de peligro [...] (1987: II, 315).

Ioachimo Camerario publica, en 1593, Symbolorum et emblematum ex volatilibus et insectis desumtorum...: en los ff. $11 \mathrm{v}-12 \mathrm{r}$, con el mote «Tuta silentio merces» se acompaña el grabado de cuatro aves — grullas aquí otra vez-volando sobre un monte en el que acechan tres águilas, que se comenta «Ne pereant clangore grues lapide ora saburrant / obstrue sic linguam garrulae, ne pereas»; más extensamente se especifica luego este ejemplo «de gruibus Taurum montem» que 
otros antiguos, dice, lo cuentan «de anseribus sylvestris», antiguos entre los que menciona a Plutarco.

Quizá la acumulación más completa de todos estos detalles se dé en el libro de fray Andrés Ferrer de Valdecebro, Gobierno general, moral y político halado en las aves más generosas y nobles (1696). Trata las «Propiedades del ansarón»:

Han de pasar por el monte Tauro precisamente, y es una eminencia que está poblada siempre de águilas; y como en su natural desasosiego no cabe estar sin graznar y hacer ruido, siempre están dando voces [...] Reconociendo, pues, el peligro que las amenaza si las águilas los oyen, cogen una piedra en el pico, y con ella pasan volando el monte seguras, prevenidas y prudentes, con silencio tanto que se van recatando de el mismo vuelo: Cumque Taurum monten Aquilis abundantem penetrare [remite luego a Valeriano, que ya he mencionado antes] (1696: 294-295).

En resumen, puede decirse que, en la mayoría de los casos, el pájaro con la piedra en el pico, emblema del silencio prudente, es el ánsar que pasa por el monte Tauro, pero no es desconocida la atribución a las grullas de este rasgo - que procede de una contaminación de motivos no del todo rara-, aunque generalmente las piedras asociadas a las grulla son las que sirven de despertador de sus centinelas y de lastre para volar en las tormentas.

Volviendo, tras este rodeo, al texto de la Arcadia, lo que dice es: «te traeré la grulla cazada en las viñas, no la centinela nocturna, que se ayuda de la piedra (en la pata); porque yo no puedo pasarme (vivir, alimentarme) con piedras; con piedras se pasa (se atraviesa) el monte Tauro (las grullas / ánades, con la piedra en el pico para precaverse del ataque de las águilas), y yo no soy el monte Tauro».

Hace un juego de dilogía en «pasar», y las piedras no son las que mantienen al monte, sino las que llevan las grullas para «pasar» el monte, y no cualquier monte, sino el Tauro. Un típico ejemplo de alusión y dilogía, formas de ingenio mental y verbal, que apelan a una curiosidad zoológica frecuente, como se ha visto, en los textos clásicos.

\section{LOS ERIZOS Y LOS MADROÑOS}

Continuando con motivos vegetales y animales menciona Alasto, algo más adelante, las guindas y los madroños que el erizo ensarta:

Las guindas rojas maduras, los madroños de las sierras, donde el erizo en sus pintas los ensarta como cuentas

(Vega, 2012: 226). 
Es una referencia al extraordinario modo en que los erizos recolectan los madroños, revolcándose para ensartarlos en sus púas cuando caen al suelo. Es otro motivo presente en los libros de emblemas y común en las zoologías al uso, desde el mismo Plinio, traducido por Jerónimo de Huerta, quien escribe al respecto:

Es admirable su industria, y así los contó Salomón entre los animales más sabios de la tierra, como declaran los setenta intérpretes, aunque la edición Vulgata en lugar de erizo traslada liebre. Prover. c. 30 Aperciben en el verano de sustento para el invierno, y para esto suben en los manzanos y perales, y meneando sus ramas hacen caer la fruta que está madura, y volcándose después sobre ella, hincada en sus espinas la llevan a su morada. Elia. de diff. ani. Lo mesmo hazen en los madroñales, y como los madroños estando maduros son blandos y fácilmente se hincan en ellos las púas, suelen llevar tantos encima, que aunque son feos parecen entonces hermosos. Crían en tiempo de la vendimia y tienen grande cuidado de sus hijos, y para darlos alimento acomodado suben entonces a las cepas, y con el hocico y pies desgranan los racimos de las uvas, y cogiéndolas en sus espinas como las manzanas las llevan a los hijos para que coman de ellas. Plu. in lib. vtra anim. [...] Los erizos se proveen de la mesma suerte de mantenimientos para los inviernos, y revolcándose sobre las manzanas las cogen en sus espinas y las llevan a las concavidades de los árboles, llevando sola una en la boca (CORDE).

Sebastián de Covarrubias Horozco (Emblemas morales, 1610: centuria I, emblema 39) trae el emblema de un erizo con las púas cargadas de madroños que responde perfectamente a la imagen aludida por Alasto en su canto. Lo comenta Peñasco González con aporte de otros testimonios:

Sobre esta estrategia del erizo nos habla Plutarco, De sollertia animalium, 16. El antecedente del emblema es muy probablemente Paradin, el emblema «Magnum vectigal» que representa al erizo tal cual lo vemos en la pictura de Covarrubias, de perfil, con las púas cargadas de frutos pequeñitos. Aunque es Bargagli quien lo presenta alejándose del árbol cargado de fruta en la empresa «Non solum nobis» que copia Camerarius, en su emblema 85 de la segunda centuria con igual mote (Symbolorum \& emblematum ex animalibus quadrupedibus desumtorum centuria altera collecta..., Leipzig, Voegelinianis, 1595) y en Capaccio en su libro tercero con lema «L'humo providente». El significado varía de un emblematista a otro, el primero recalca del erizo su capacidad de aprovisionarse y administrarse. Covarrubias, por su parte, ve en el erizo no una virtud, sino un vicio, pues hartado de comer, aún se lleva más alimento consigo (2015: 229, n. 159).

El motivo, como se ha visto, muy insertado en el mundo de los emblemas, pasa también al refranero, como recoge Rodríguez Marín (2007): «Si vieres el erizo cargado de madroños, ¿preguntarás cuándo entra el otoño?». 
5. LA MUERTE De Hitólito: ¿FOCA O TORO?, ¿ERROR De Lope?

Sigue Alasto ofreciendo su cornucopia de vegetales, frutas, animales de aire, tierra y acuáticos, entre otros,

\author{
las focas, con quien Teseo \\ mató a Hipólito por Fedra \\ y hasta las ballenas grandes \\ que el ámbar precioso engendran
}

(Vega, 2012: 230).

Lo cual anota Sánchez Jiménez:

Fedra se enamoró de su ahijado Hipólito, pero al rechazarle este le acusó ante su marido Teseo de haberla forzado («Exposición»). Teseo hizo que Neptuno matara a su hijo con un toro monstruoso - no con focas - que espantó a sus caballos.

En muchas versiones del mito, en efecto, Hipólito (más que «ahijado», alnado o hijastro de Fedra) muere aplastado cuando los caballos de su carro son espantados por un toro que envía Neptuno o por los «becerros marinos», como traduce a Plinio Jerónimo de Huerta (CORDE).

En las fundamentales Metamorfosis de Ovidio es, ciertamente, un toro que sale de las olas: «corniger hinc taurus ruptis expellitur undis / pectoribusque / tenus molles erectus in auras / naribus et patulo partem maris evomit ore» (lib. 15, vv. 511-513, sobre Hipólito).

Que Lope mencione las focas en vez del toro, pudiera ser un error del poeta, lapsus u olvido (que es lo que parece implicar la nota del editor), o bien una adaptación original para mejor integración en la serie de animales marinos, o pudiera ser que siga otra versión del mito con focas en vez de toro. Esto último es realmente lo que sucede.

En algunos relatos de la historia de Hipólito son las «focas» —no un toro- las que asustan a sus caballos, así lo recoge Natale Conti en su Mitología:

Theseum Phædræ uxoris precibus commotum a Neptuno patre impetravisse ut Hippolytum filium necaret quem Phædra falso accusauit tentatæ pudicitiæ quia nouercæ libidini noluisset assentiri. Neptunus phocas Hippolyto iuxta litus maris vecto in curxu immisit quibus tanta trepidatio equis iniecta est ut in fugam versi illum e curru delapsum discerpserint quare Phedra postmodo poenitentia ducta, vt plerique senserunt laqueo vitam finiuit (1611: 164).

Ya en el comentario de Servio ${ }^{12}$, Teseo ruega a Egeo (no a Neptuno) que envíe una foca: «[Teseo] ille Aegeum patrem rogavit ut se ulcisceretur, qui agitanti

12 Tomo estas citas de Moya del Baño (1969: 29). 
currus Hippolyto inmisit focam, qua equi territu eum traxerunt» (Eneida, VII, 761). Y el mismo Servio: «invocavit Aegeum patrem, qui Hippolyto currum agitanti inmisit phocam» (Eneida, VI, 445).

De Servio toma el motivo de las focas Boccaccio (De casibus illustrium virorum, I, X, 22, «De Teseo»), en donde son unas focas que andan por la ribera del mar («pascentes in littore phoce») las que provocan el accidente de Hipólito.

Entre otros, el padre Vitoria en el Teatro de los dioses de la gentilidad adopta la versión de las focas: «huyendo Hipólito del paternal furor y guiando su camino en un carro orillas del mar, saliendo las focas, espantaron y alteraron los caballos y despeñaron al casto mancebo» (1702: p. I, lib. IV, 438).

Que no es error u olvido de Lope lo confirma la mención de las focas de Hipólito en la Jerusalén conquistada:

Parecían asidos por brandales trizas y escotas como al olmo hiedra, aquel lienzo de varios animales que vio el apóstol de la Iglesia piedra, como del mar las focas desiguales al casto joven de la incasta Fedra, así contra los reyes con discordes silbos iban saliendo por los bordes (lib. 9, 27).

Son, pues, en efecto, focas, las que provocan la muerte de Hipólito y Lope no yerra. Simplemente se acoge a esta versión.

\section{ISMENIAS TEBANO ¿OTRA CONFUSIÓN DE LOPE?}

Tampoco yerra Lope cuando evoca al «Ismenias tebano», que «tañendo y cantando curaba los frenéticos» (247), y que Sánchez Jiménez considera una confusión del Fénix:

Ismenias curaba a los locos con el poder de su música (Ravisius Textor, Officinae, vol. II, pág. 102). Lope confunde su patria, pues el médico Hismenias no es el mismo que el «Ismenias thebanus», embajador de Tebas sobre el que cuenta otra anécdota Ravisus Textor (Vega, 2012: n. 228).

Ravisus Textor señala que «Hismenias tibicen fuit peritissimus» y que aliviaba muchas dolencias con la música («multis aegritudines laborantibus omnes animi molestias abstersit», II, 92). No aclara mucho más. 
Plutarco en Vida de Artajerjes, o Claudio Eliano en Historias curiosas (lib. I, 21) cuentan la anécdota — a la que alude Sánchez Jiménez, pero que no hace aquí al caso- del Ismenias tebano que para evitar la reverencia obligada ante el rey de Persia, echa el anillo al suelo y a la vez que lo recoge se inclina «evitando» reverenciar al persa, porque «se inclina para recoger su anillo». Pero este no es el Ismenias al que Lope quiere referirse, ni se equivoca al mencionar al «Ismenias tebano», músico curador que sana a los frenéticos con su música, porque hay otros textos que transmiten esa historia y la procedencia tebana del tal Ismenias del que Textor recoge pocos detalles, pero que aparece, por ejemplo, en la Silva de varia lección de Pero Mexía: «de Ismenias, tebano, leemos que curó a muchos de dolores y otras enfermedades tañendo con la flauta suavísimamente» (1989: 88), con nota de Antonio Castro que ilumina algunos aspectos de la referencia:

Ismenias: Ismenio, sobrenombre de Apolo en Tebas, cuyo templo, denominado Ismenium, se encontraba delante de las puertas de la ciudad. Entre las diversas potestades que se le adjudicaban Apolo estaba considerado como dios de la música. Otra tradición lo hace dios de Tebas e hijo de Apolo (Mexía, 1989: 88, n. 7).

Pero Mexía cita juntos a Asclepíades, quien «escribe que a los frenéticos y que tienen enajenado el sentido les aprovecha cantalles y tañelles dulce y acordadamente» (1989: 87-88), y a Ismenias, lo mismo que Lope, que muy probablemente se basa en la Silva para estas menciones.

De todas formas, en numerosos textos aparece «Ismenias tebano» como músico que curaba con la armonía de sus sones a los enfermos. Johannes Casus (John Case) en Apologia musices tam vocalis quam instrumentalis et mixtae:

Quomodo Ismenias Thebanus quamplurimos grauitèr aegrotantes curaret? quomodò denique alij penè innumeri musicis sonorum modulis et concentibus alia multa obstupenda facerent, certè non video, nec olim (quos lego) Philosophi perspexerunt (1588: IV).

Es posible que una de las fuentes del motivo sea Boecio, de quien recuerda Suárez de Figueroa: «Refiere Boecio haber sanado Ismenio tebano a muchos que tenían dolores en los muslos con la melodía» (1629: 403) ${ }^{13}$. Lo recogerá más tarde también el padre Feijoo como lugar común: «A Asclepíades se atribuye la curación de los frenéticos con el mismo remedio [la música] y a Ismenias tebano de la ciática y otros dolores» (Teatro crítico, discurso 12, 32).

13 Boethius, De institutione musica: «Ismenias vero Thebanus Boeotiorum pluribus, quos ischiadici doloris tormenta vexabant, modis fertur cunctas abstersisse molestias». El pasaje lo citan luego otros muchos. 
Hay, por otra parte, varios Ismenias tebanos que no se identifican con el médico musical y que no interesan para este lugar de la Arcadia. Es probable que en muchos textos este Ismenias músico haya nacido como avatar del Apolo Ismenio que anota Castro para la Silva de Mexía. En cualquier caso Lope que, en efecto, había leído y asimilado y recordado muchas más cosas de las que a menudo los comentaristas creemos, no yerra al mencionar el tal Ismenias tebano que curaba tañendo y cantando.

\section{El DESPOSADO NECIO}

En las quejas de Celso se hace referencia, en cierto momento, a la necedad del desposado: «Necio dicen que, en efecto, / ha de ser el desposado» (Vega, 2012: 258), que pasa sin nota en las ediciones, y que convendría apuntar que se trata de otro motivo tradicional, alusivo a la idea de que la primera palabra que dice un novio es una necedad. Así aparece en los Cuentos de Garibay, donde se adapta al caso de un desposado realmente necio:

Un padre tenía un hijo necio, y quiriéndole desposar, encomendole mucho que no hablase, porque no entendiesen que era necio. Y estando todos asentados a la mesa, los parientes de la novia dijeron que parecía el desposado necio, como no le vían hablar; y oyéndolo el desposado, dijo a su padre:

- Señor, bien puedo ya hablar, que me han conocido (CORDE).

\section{Castillo Solórzano en La garduña de Sevilla:}

Estuvo el galán caballero muy gustoso en la visita y muy despejado, sin que se le pudiese notar la primera necedad de los novios, porque era don Pedro de claro entendimiento y de galán despejo (CORDE).

Y en la famosa Floresta española de Melchor de Santa Cruz, en varias formulaciones:

Yéndose uno a desposar, avisole el padrino que parase mientes que la primera palabra que dijese a su esposa fuese avisada, porque los más suelen decir entonces necedad. Díjole:

- Señor, bien pensada la tengo.

Replicó el padrino:

- Siendo bien pensada ${ }^{14}$, de razón será bien gorda.

A uno diéronle poder para que se desposase por otro. Y, en desposándose, sentose cerca de la desposada. Y, como no hablase, preguntáronle por qué callaba. Respondió:

\footnotetext{
14 Juega con el sentido 'alimentada con pienso'.
} 
- Señores, no me dieron poder para decir la primera necedad.

Un gran necio iba muy pensativo a desposarse. Dijo uno:

— ¿Qué va pensando nuestro desposado?

Respondió otro que iba cerca de él:

-En la primera necedad que ha de decir.

Acudió el primero, diciendo:

-En casa llena presto se guisa la cena $(C O R D E)$.

A esto se refiere Celso en sus versos.

\section{El Monte de la Luna}

Dos veces se menciona en la Arcadia el monte de la luna (o mejor Monte de la Luna). En la canción de Galafrón a las lágrimas: «¿de qué Tesalia o monte de la luna / has cogido las hierbas de Medea?» (Vega, 2012: 301); y en la ponderación que hace Galafrón de las habilidades de Polinesta, «la más famosa hechicera del Arcadia, donde si no hallas remedio no hay para qué buscarle en el monte de la luna ni en toda la peregrinación de Medea» (Vega, 2012: 550).

En los dos casos se relaciona con la hechicería y las hierbas venenosas. En la primera ocasión Sánchez Jiménez anota la calidad hechiceril de Medea, sin reparar en el monte, y en el segundo explica que «En la luna depositaba Ariosto las cosas perdidas, como el seso de Orlando», en seguimiento de una nota errada de Morby, en la que el erudito americano cree la referencia «probable recuerdo del Orlando furioso de Ariosto [...] en que la luna es el depósito de las cosas perdidas, como por ejemplo el seso de Orlando» (1975: 353).

Este Monte de la Luna - mejor en mayúscula, como nombre propio- no se refiere a la orografía del satélite, sino a una región en el nacimiento del Nilo, caracterizada por la proliferación de hierbas venenosas. En el anónimo Libro de astrología (hacia 1500), hay un capítulo "del Monte de la Luna», donde se lee:

Dicen los filósofos que esta tierra que non entra ninguno en ella de parte de la mucha calentura \& otras cosas muchas. Dicen porque es deshabitada esta parte meredional de la tierra $\&$ en aquella tierra es un monte que se llama el Monte de la Luna, porque luego, como nace la luna, lo más alto deste monte se para luciente de luz clara \& blanca \&, como va creciendo la luna, la noche segunda crece más la blancura; e a la noche tercera cúbrese de luz que tira a amarilla $[\ldots]$ \& sale de aquel monte el grand río llamado Nilo (CORDE).

Cervantes, en el Quijote, recuerda estos montes como el lugar de nacimiento del Nilo («aquella agua en cuya busca venimos, que parece que se despeña y 
derrumba desde los altos Montes de la Luna» (1947-1949: I, 20), y es lugar conocido en las misceláneas como la de Torquemada, Jardín de flores curiosas, «el río Nilo nace, según se ha dicho, en África, cerca del monte Atlas [...] aunque según parece por la navegación de los portugueses que lo descubrieron es en los montes que llaman de la Luna, acercándose hacia mediodía» (2012: 691-692).

Calderón menciona con mucha frecuencia el Monte de la Luna en sus autos ${ }^{15}$ y siempre en relación con la hechicería y los venenos: en el de La vida es sueño, la Sombra dice que aprendió magia en «el Monte de la Luna, / templo de la noche»; en El jardín de Falerina, el Lucero sale, según una acotación, «del primer carro, que será de Infierno» y pronuncia estas palabras: «iOh, tú, parda columna / del venenoso Monte de la Luna, / cuya pálida tez, lóbrega y fría / sobre los verdes tósigos que cría / de la cicuta, el opio y el beleño / catres le mulle a la deidad del sueño!»; en El tesoro escondido leemos: «iAh del lóbrego seno / del Monte de la Luna, / de cuyo vientre abortos / son el beleño, el opio y la cicuta!»; en El pintor de su deshonra, el Lucero apostrofa a la Culpa: «iOh, tú! que el pavoroso oscuro centro / de ese peñasco habitas escondida, / mientras no te declaras homicida / lid de la Gracia, siendo escandalosa / de la más dulce paz, caliginosa / madre letal del sueño, / alimentando monstruos del beleño, / que engendra el negro Monte de la Luna...»; en La cena del rey Baltasar, la Muerte declara que «con el opio y el beleño / de los Montes de la Luna / entorpece la fortuna / mi imagen pálida, el sueño»; las primeras palabras que pronuncia el Demonio en El valle de la Zarzuela son: « ¡Oh tú, parda columna / del tenebroso Monte de la Luna, / cuya pálida luz, trémula y fría, / sobre las yerbas y áspides que cría / de la cicuta, el opio y el beleño / catres le mulle a la deidad del sueño»...

Aunque generalmente se sitúan en el citado nacimiento del Nilo, no falta la localización en Tesalia, tierra de hechizos y venenos, con la que se asocia estrechamente este Monte de la Luna, que es más que nada un mito. En el auto calderoniano de El verdadero dios Pan, Pan reside al comienzo de la obra en el Monte de la Luna, esta vez situado en Tesalia:

Este Monte, que a la Luna consagró en templo Tesalia — más de miedo que de amor, por ser el que en sus entrañas, siendo asilo de las fieras, es veneno de las plantas - no obstante su horror, abriga a la sombra de su falda tan numerosos rebaños,

15 Para localizar estos pasajes de los autos remito a Arellano (2011, s.v.). 
que apuran, roban y talan tal vez su cristal al río, tal al valle su esmeralda.

Con que, habiendo dicho que esen una parte abundancias y en otra horrores, no habré menester decir con cuánta propiedad se representa, como en abreviado mapa, el Mundo en él

(Calderón, 2005: vv. 191-208).

Y parece que el propio Lope, en El peregrino en su patria, lo sitúa también en Tesalia:

Cuando de hierbas de Tesalia trate, y discurriendo el Monte de la Luna los espíritus ínfimos maltrate, no hay fuerza en hierba ni en palabra alguna contra mi voluntad, que hizo el cielo libre en adversa y próspera fortuna (2016: 393).

\section{EL JUEGO DE LOS PROPÓSITOS}

Los pastores y las pastoras de la Arcadia, entre canciones, celos, tareas y galanteos, se entretienen también con algunos juegos, entre ellos «mayormente el de los propósitos» (Vega, 2012: 309), juego que hay que entender en el contexto como una estrategia más de los cortejos, ya que los implicados se acogen a ese juego porque «solo pretendían declarar los suyos» (esto es, sus propósitos).

Aunque no ha perdido totalmente vigencia, es poco probable que un lector moderno entienda el funcionamiento de la escena y las implicaciones del juego, sin una aclaración. Así parece entenderlo el editor, que pone una nota al texto; nota, sin embargo, que poco puede aclarar en su reducida formulación («es un entretenimiento de ambos sexos», definición que toma de Covarrubias, quien dice realmente «es un entretenimiento de doncellas» $)^{16}$. Lo que importa es comprender el desarrollo del juego, que explica detalladamente, en relación con un texto de La Galatea cervanti$\mathrm{na}^{17}$, Óscar Perea Rodríguez, de quien tomo los siguientes pasajes:

${ }^{6}$ Curiosamente la equivocación en la cita del Tesoro hace a Sánchez Jiménez acercarse más a la organización real del juego. Ver los comentarios que copio de Perea Rodríguez.

17 «Francenio y Lauso, que están presentes, se hallaron en una conversación de hermosas pastoras, entre las cuales, por pasar sin pesadumbre las horas ociosas del día, entre otros muchos juegos, ordenaron el que se llama de los propósitos. Sucedió, pues, que, llegando la vez de proponer y 
Con los participantes habitualmente sentados en corro, el juego consistía en decir al oído de la persona más cercana un pensamiento secreto; cuando todos habían completado la acción, generalmente siguiendo el sentido de las agujas del reloj, el participante que había escuchado el secreto respondía con una frase al interesado, sentencia lo suficientemente ambigua e ingeniosa como para dejar entrever a todos con la respuesta cuál era la confidencia que le había sido confiada en susurros. [...] por mucho que Covarrubias se empeñe en su definición diciendo que es un entretenimiento de doncellas, la diversión cortesana debió de unir a hombres y mujeres desde épocas muy tempranas. [...] Otras menciones al juego de los propósitos insisten en este componente de desorden, si bien a veces no parecía tan divertido. Así, Góngora se queja en una de sus epístolas de esos parientes que juegan a los propósitos, diciéndose los dos una cosa al oído y saliendo otra. Tirso de Molina, en su comedia La huerta de Juan Fernández, vuelve a presentar a hombres y mujeres unidos en este entretenimiento, al hacer exclamar al personaje de Laura: «los propósitos jugamos, / y son tan firmes los míos / en materia de quererte, / que por causa tuyo olvido / parientes obligaciones». Otro comediógrafo áureo, Luis Vélez de Guevara, también hace aparecer a un grupo mixto (Úrsola, Pelayo y Gila), practicando varios entretenimientos cortesanos, entre ellos el juego de los propósitos, en su obra El conde don Pero Vélez $y$ don Sancho el Deseado (1615). Por último, hay que mencionar el contrafactum a lo divino del maestro de estas lides en el Siglo de Oro, Alonso de Ledesma, que no dudó en utilizar el juego de los propósitos para moralizarlo en clave religiosa en uno de sus poemas publicados en 1611 en su obra Juegos de Nochebuena (2010: 6.515).

Perea da como primera mención del juego en la literatura del Siglo de Oro esta de la Arcadia, pero la de La Galatea cervantina es anterior.

\section{LOS OJOS DEL AVE NICTÁLOPE}

En la canción de Brasildo se suceden los elogios a la belleza de una gentil ninfa, cuyos ojos negros se comparan con los del «ave que ve de noche», por la capacidad de atraer, los de una a las aves de «mil nombres», los de la otra a «los hombres», en un pasaje que no recibe nota y que es poco probable que un lector moderno comprenda sin alguna ayuda.

El texto es:

como a los del ave

que ve de noche acuden de mil nombres,

así a tu luz los hombres (Vega, 2012: 372).

comenzar a uno destos pastores, quiso la suerte que la pastora que a su lado estaba y a la mano derecha tenía, fuese, según él dice, la tesorera de los secretos de su alma, y la que por más discreta y más enamorada en la opinión de todos estaba. Llegándosele, pues, al oído, le dijo: Huyendo va la esperanza. La pastora, sin detenerse en nada, prosiguió adelante, y al decir después cada uno en público lo que al otro había dicho en secreto, hallose que la pastora había seguido el propósito, diciendo: Tenella con el deseo» $(C O R D E)$. 
Se entiende «a los ojos del ave que ve de noche»: es decir, el búho. El rasgo de acudir a los ojos del búho otras muchas aves («de mil nombres», aunque se destaquen especialmente los cuervos) se relaciona a menudo con la envidia que la belleza de dichos ojos provoca en las otras aves, o bien con la atracción que produce su resplandor. Es motivo reiterado que a propósito de un pasaje del Quijote comenta Rodríguez Marín (1947-1949) ${ }^{18}$, con citas de Álvaro Cubillo de Aragón y Agustín de Salazar y Torres. Los dos textos que cita Rodríguez Marín mencionan el uso del búho como señuelo para cazar aves atraídas por los ojos del pájaro nocturno que exhiben durante el día; cuando las aves se acercan, bien para admirar la belleza de esos ojos, bien para atacarlos con envidia, las aves de presa preparadas se lanzan sobre las víctimas atraídas por el cimbel:

\author{
al búho gallego, cuyos ojos \\ señuelo son para cazar las aves \\ que admiradas a verlos se le llegan \\ y con pecho sencillo e ignorante \\ dan en las garras del halcón rapante, \\ siendo para prenderlas trampa o liga \\ (Cubillo de Aragón, 1654: 18-19). \\ Ya el búho prevenido \\ en el llano tenía el halconero, \\ y el pájaro agorero \\ ofrecía a las cuervas por despojos \\ el oro de sus ojos, \\ que este metal de suerte los inclina \\ que a su esplendor se arrojan presurosas
}

(Salazar y Torres, 1694: 86).

La técnica de usar los ojos del búho como señuelo la comentan los manuales de cetrería, por ejemplo, el de Alonso Martínez de Espinar, Arte de ballestería y montería:

el búho del tamaño del águila, de más cortas plumas y más bajo vuelo; [...] los ojos mayores y más resplandecientes que todas las demás aves [...] son grandísimos cazadores $[\ldots]$ que tienen en la oscuridad mucha vista; donde quiera que esté escondida la caza la ven y la matan [...] son por esta causa las aves sus enemigos; y así, cuando de día le aciertan a descubrir, le persiguen y llegan a picar los ojos; particularmente le siguen las picazas, cuervas y rendajos, las cuales cacarean y hacen mucho ruido para juntar otras aves, que todas acuden a él (1644: XXXIV, 417-418).

18 En su edición del Quijote (I, 377-378). Reutilizo algunos materiales de Arellano (2016). 
En el siglo XvIII, Agustín Calvo Pinto, en su Silva venatoria, para explicar por qué se cazan los búhos por la noche, ofrece una variante, fundamentada precisamente en la envidia por la hermosura de los ojos: «Dicen algunos naturales que el cazar estas aves de noche [búhos] es porque las otras aves de rapiña, envidiosas de la hermosura de sus ojos, no se los saquen» (1754: 125).

Góngora tuvo en cuenta esta imagen en varios lugares. En el romance «Triste pisa, y afligido» (n. ${ }^{\circ} 22$, vv. 41-48), le sirve para expresar la velocidad con que un enamorado moro se «lanza» a los ojos de su amada. Antonio Carreira (1998), a propósito de este romance recuerda otra mención del motivo en «Aunque entiendo poco griego»:

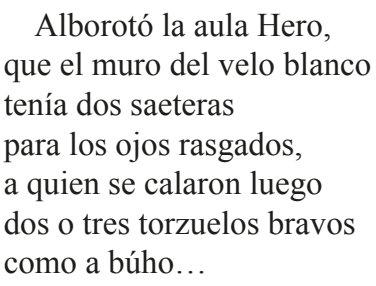

(1998: n. ${ }^{\circ} 63$, vv. 85-91).

Y en su nota a este último aduce otros textos de Liñán y Verdugo («se andaban tras las visitas que ella hacía o le hacían como tras de los ojos del búho las otras aves»), Zabaleta («en saliendo a donde los otros pájaros están no le dejan sosegar los otros pájaros. Unos embisten a sacarle los ojos...»), o Castillo Solórzano («Cual tropa de varias aves / suele en giros importunos / de su luz aficionada / seguir los ojos del búho»).

Góngora desarrolla sobre todo la imagen con lujo de alusiones en la segunda Soledad (vv. 891-901). Salcedo Coronel, en su comentario de las Soledades, escribe sobre el búho:

Es del tamaño de un águila esta ave, pero de más recogido y corto cuello, $[\ldots]$ los ojos mayores y más resplandecientes que todas las demás aves [...] huye de los rayos del sol, y busca en la noche el sustento, sirviéndole sus ojos de antorchas con que le halla y descubre, y si alguna vez vuela de día es perseguido de todas las aves y llegan a quitarle las plumas, invidiosas por ventura de sus ojos; por esta causa le ponen los cazadores junto a las redes, para hacer acudiendo las aves mayor presa de ellas (1636: f. 293v).

\section{Y Pellicer en las Lecciones solemnes:}

comenzó a tender las alas [el búho] ocupando un verde poso, que es un montoncillo de tierra y piedras que hacen los cazadores para que se pose el búho y vengan las 
aves a los ojos [...]. Caláronse diez y diez y ciento a ciento al oro intuitivo, a los hermosos ojos del búho (1630: cols. 603-604).

\section{El PÁJARO SOLITARIO}

Anfriso, sentado sobre una peña y suspirando sus quejas amorosas, se compara con un «pájaro solitario» que se queja en secos árboles (Vega, 2012: 382), pasaje que no merece nota de los editores (Morby, 1975: 221), pero del que conviene aclarar un detalle que pudiera implicar algunos ecos intertextuales. Se trata de precisar que en el pasaje «solitario» no es adjetivo que se aplica a un pájaro cualquiera, sino un sustantivo que nombra al pájaro así llamado y que el Diccionario de autoridades define como:

Ave algo mayor que el gorrión. Su color es negro con unas pintas blancas [...] Llámase así porque por la mayor parte vuela solo. Es de especie y linaje de los tordos. Habita ordinariamente en los tejados de las casas viejas y desiertas de moradores. Su canto es muy suave.

La comparación del poeta o el enamorado con el pájaro solitario es frecuente y aparece en Petrarca, Canzoniere, soneto CCXXVI: «Passer mai solitario in alcun tetto / non fu quant'io» que tiene a su vez ecos de «Vigilavi, et factus sum situt passer solitarius in tecto» (Salmos, 101: 8). Aunque en alguna ocasión pudiera entenderse «solitario» como mero adjetivo, la identificación con una especie concreta se reitera en muchos textos, orientando la interpretación de las menciones en el Siglo de Oro. Aquilecchia resume algunos casos relacionados con Petrarca y un poema de Leopardi, enumerando algunas presencias del pájaro solitario en poesías renacentistas:

i versi del Pulci, Morgante, XIV, 60: La passer penserosa e solitaria | che sol eon seco starsi si diletta; [...] strambotto di Pamfilo Sasso: Come fa il passer solitario in volo, | piangendo la mia cruda e triste sorte; il capitolo di Benvenuto Cellini sulla prigione: Cantava un passer solitario forte $\mid$ sopra la rocca; $\mathrm{e}$ - meno noto, ma forse più direttamente legato al tema leopardiano - il sonetto di Giovanni Botero [«al passero solitario»]: Gentil augel, che su solingo tetto' (1978: «Abstract»).

San Juan de la Cruz desarrolla una serie de cualidades simbólicas del solitario aplicadas a sus experiencias místicas, muy lejanas sin duda de las del personaje de la Arcadia:

Este conocimiento [de la divina luz] entiendo quiso dar a entender David cuando dijo: Vigilavi, et factus sum sicut passer solitarius in tecto; que quiere decir: Recordé y fui hecho semejante al pájaro solitario en el tejado (Ps 101, 8). Como si dijera: Abrí los ojos de mi entendimiento y halleme sobre todas las inteligencias naturales, solitario sin ellas en el tejado, que es sobre todas las cosas de abajo. Y dice aquí que fue hecho semejante al pájaro solitario, porque en esta manera de contemplación tiene el espíritu 
las propriedades deste pájaro, que son cinco: La primera, que ordinariamente se pone en lo más alto; y así el espíritu en este paso se pone en altísima contemplación. La segunda, que siempre tiene vuelto el pico [hacia] donde viene el aire; y así el espíritu vuelve aquí el pico de afecto hacia donde viene el espíritu del amor, que es Dios. La tercera es que ordinariamente está solo y no consiente otra ave alguna junto a sí, sino que, en posándose alguna junto, luego se va; y así el espíritu en esta contemplación está en soledad de todas las cosas, desnudo de todas ellas, ni consiente en sí otra cosa que soledad en Dios. La cuarta propriedad es que canta muy suavemente; y lo mismo hace a Dios el espíritu a este tiempo, porque las alabanzas que hace a Dios son de suavísimo amor, sabrosísimas para sí y preciosísimas para Dios. La quinta es que no es de algún determinado color... (López Baralt, 1984: versión en línea).

Más cercano al pastor lopiano sería el amante del soneto de Quevedo ${ }^{19}$, que aprende a lamentarse del pájaro solitario:

Músico llanto en lágrimas sonoras

llora monte doblado en cueva fría, y destilando líquida armonía hace las peñas cítaras canoras.

Ameno y escondido a todas horas,

en mucha sombra alberga poco día; no admite su silencio compañía; solo a ti, solitario, cuando lloras. Son tu nombre, color y voz doliente señas más que de pájaro de amante; puede aprender dolor de ti un ausente. Estudia en tu lamento y tu semblante gemidos este monte y esta fuente, $\mathrm{y}$ tienes mi dolor por estudiante.

\section{Comenta González de Salas:}

Refiriome don Francisco que en Génova tiene un caballero una huerta y en ella una gruta hecha de la naturaleza en un cerro, de cuya bruta techumbre menudamente se destila por muchas partes una fuente con ruido apacible. Sucedió, pues, que dentro della oyó gemir un pájaro que llaman solitario y que al entrar él se salió y en esta ocasión escribió este soneto.

\section{La maraVillosa AgUiJadA DE BAMBA}

En la galería de personajes notables aparece el rey Bamba con su aguijada en la mano: «aquel que en la una mano tiene un aguijada florida y en la otra un cetro de

19 Remito a mi edición de El Parnaso español de Quevedo, para estos textos del poeta y de González de Salas. 
oro es el godo Bamba, a quien España debe los principios de su policía» (Vega, 2012: 389-390). Sánchez Jiménez añade una nota de cierta extensión (la 506) sobre el rey y su leyenda:

El rey visigodo Wamba (Bamba) reinó entre 672 y 680. Según la leyenda era campesino - por eso se le representa con la aguijada para azuzar a los bueyes—, pues se le eligió de acuerdo a una profecía que decía «que lo fallarían en las partes más vaxas d'España contra la mar e que lo fallarían arando con un buey blanco e con otro vermejo» (García de Salazar, Historia de las bienandanzas, lib. XIII, «Título del enreinamiento del noble rey Banba», f. 229r). La Estoria general de Alfonso X trata de modo más general la elección de Wamba (pág. 284). En el Isidro, Lope le vuelve a mencionar como «villano y rey» (canto X, v. 902). Lope escribió sobre el tema su comedia Vida y muerte del rey Bamba, antes de 1598, y por tanto contemporánea de esta Arcadia y el Isidro (Morby, 1975: 228) ${ }^{20}$.

En la página 402 vuelve a mencionar en las redondillas que acompañan a las imágenes las «insignias dos / que rigen vasallo y buey» de Bamba (el cetro y la aguijada), explicadas algo superfluamente por Sánchez Jiménez (n. 547) como «la aguijada, para dirigir a los bueyes y el cetro, para gobernar a los hombres».

Estas notas, sin embargo, no proporcionan ilustración para el detalle verdaderamente relevante que atañe a la aguijada de Bamba. Es cierto que el dato de guiar un buey blanco y otro bermejo puede servir para identificar al elegido por la mano divina para gobernar el reino, pero ese dato no aparece en el texto de Lope y no implica dimensión maravillosa. Lo maravilloso, marca de la divina elección, es que la aguijada de Bamba florezca («aguijada florida»).

Es motivo tópico en la evocación del rey Bamba; tomo del CORDE los siguientes ejemplos:

Y nuestro rey Bamba de las Españas, que fue excelente rey, fue hallado con una aguijada en la mano cuando le vinieron a dar la obidiencia por rey y a llevarlo a Toledo. Y pareciéndole cosa de burla y escarnio que él fuese elegido por rey, dijo burlando: «Cuando esta mi aguijada tuviere hojas, seré yo rey de los godos». Y luego la aguijada floreció y llevó flor y hojas y fruta (Arce Otálora).

Bamba fue elegido rey de España. Y lo fue muy valeroso por muerte del rey Recisundo. Y segund se lee aunque era de la casta de los godos, labrador era que estaba arando con un par de bueyes cuando le fueron a buscar para elegirle por rey segund más largo cuenta Valerio de las historias escolásticas y de España, [...] aunque si aquello que allí se escribe es verdad del florecer de la aguijada, misterio fue divino (Sebastián de Horozco).

20 Morby, en el lugar aludido por Sánchez Jiménez, se limita a recordar que Lope escribió sobre el tema en la citada comedia. 
una vara que traía, ya después de hincada en tierra estas palabras decía.

Cuando esta vara florezca yo seré rey de Castilla.

Aun no lo hubo bien dicho

la vara ya florecía

(Romance anónimo del rey Bamba).

No podía faltar, por tanto, en la comedia del mismo Lope, Vida y muerte del rey Bamba, donde se plantea el conflicto de la sucesión del reino, y deciden los godos que será rey quien proponga el papa. Un ángel anuncia al pontífice que Dios:

Rey tiene elegido

el cual arando se hallará en España

con dos bueyes, uno rojo y otro blanco,

el cual tendrá por sobrenombre Bamba

(Vega, 1604: f. 99v).

Los nobles regresan de Roma, y hallan a Bamba arando, pero él rechaza la propuesta absurda que le hacen:

\begin{tabular}{|c|c|}
\hline BAMBA & $\begin{array}{l}\text { Suspenso y embelesado } \\
\text { me estoy del caso admirando. } \\
\text { ¿Cuándo, Dios, merecí, cuándo } \\
\text { ser elegido y llamado? } \\
\text { Yo no lo puedo creer; } \\
\text { porque veo que me falta. } \\
\text { para persona tan alta } \\
\text { el valor y el merecer. }\end{array}$ \\
\hline ERBICIO & $\begin{array}{l}\text { Digo que te está guardada } \\
\text { España por justa ley. }\end{array}$ \\
\hline BAMBA & $\begin{array}{l}\text { Así puedo yo ser rey, } \\
\text { como dar flor mi aguijada. } \\
\text { Florece el aguijada } \\
\text { (Vega, 1604: f. } 103 \text { r). }\end{array}$ \\
\hline
\end{tabular}

\section{La Santa Casa}

La Santa Casa que el rey Jaime (el Conquistador) hubiera podido ganar «si el tiempo, con furia tanta / no me hiciera resistencia» (Vega, 2012: 406) no es «Jerusalén, o en general, los Santos Lugares», sino la Santa Casa de la Virgen María, cuya historia traza por ejemplo el padre Horacio Turselino, traducido por 
el padre Juan de Rojas, en su Historia Lauretana en que se cuentan las translaciones, milagros, y sucesos de la santa Casa de Nuestra Señora de Loreto compuesta en lengua latina por el padre Horacio Turselino (1603), y que sirvió a Calderón para el argumento del auto sacramental A María el corazón. Se trata de una leyenda piadosa muy extendida, según la cual los ángeles trasladaron la casa de la Virgen desde Nazaret, a través de varias estaciones, pasando por Dalmacia hasta una heredad de la dama Laureta en Italia (que dará para siempre el nombre a la Casa, llamada luego «de Loreto»). Esto escribe, entre otras cosas, Turselino, en la versión del padre Rojas:

por haber sido obrado en ella [la casa de Narazeth], mediante la salutación angélica, el inefable misterio de la encarnación del Hijo de Dios, [...] fue siempre estimada y reverenciada la santidad de aquel lugar, con suma veneración de los primeros cristianos: teniendo por autores y maestros de su devoción a los sagrados apóstoles; los cuales para avivar y conservar la piedad y religión de la Iglesia tierna, y para perpetuar en todas las edades la memoria de tan inefables sacramentos, consagraron aquella celestial casa, celebrando en ella los divinos misterios. Y así desde aquellos primeros tiempos los santos apóstoles por sí mismos, con suma devoción, reverenciaron aquellos sacros lugares y con su ejemplo y doctrina lo enseñaron a los fieles; y de los apóstoles y dellos, de padres a hijos, se fue conservando por muchas edades la religión con que eran adoradas aquellas humildes paredes, que eran las memorias que habían quedado como testigos visibles del sagrado nacimiento de la Virgen Nuestra Señora, y de la encarnación del Verbo en sus entrañas (Arellano, 1999: 75-76, v. 61).

El rey Jaime pretendió conquistar Jerusalén, organizando dos cruzadas (1269 y 1274), pero ambos intentos fracasaron. El primero, el más empeñoso, se inició con la partida de una flota el 4 de septiembre de 1629, pero una tormenta la obligó a refugiarse en Aigues Mortes, cerca de Montpellier (la furia del tiempo que menciona el poema de Lope). La mención concreta de la Santa Casa de la Virgen - que pudiera entenderse como metonimia por los Santos Lugares, pero que no se identifica exactamente con ellos - alude precisamente a la devoción mariana característica de este rey ${ }^{21}$.

\section{Eneas, Criseida y Creúsa. Lope tampoco aquí se confunde}

Un problema que no se ve con claridad si incluye una errata o un error del anotador se advierte en la referencia a Eneas y su mujer, de la canción de Lucindo:

21 Ver Alejos Morán (1995) para este asunto de la devoción mariana del rey Jaime. 
Huir de Troya, aunque era fuego, pudo sacando a su mujer Eneas troyano y yo a mi libertad de nieve dudo

(Vega, 2012: 453).

Sánchez Jiménez enmienda de nuevo a Lope al señalar que «Fue a su padre, Anquises, y no a su mujer Criseida [sic] a quien el piadoso Eneas libró del fuego de Troya. De hecho Criseida [sic] murió entre las llamas. Se confunde Lope, pues» (2012: 453, n. 664). Ya Morby veía una desviación de Lope, aunque le daba el beneficio de la duda: «Lope se aparta aquí, probablemente de intento, de la tradición más conocida, según la cual Eneas saca de una Troya en llamas a su padre Anquises, mientras que Creúsa, su mujer, perece» (1975: 279, n. 118).

Es poco verosímil que Lope se confunda en un detalle semejante de una obra tan importante como la Eneida. Y, en efecto, no se confunde el poeta, sino en este caso el anotador. El nombre de la mujer de Eneas es Creúsa, no Criseida, que es la hija de Crises, sacerdote de Apolo, que aparecen en la Ilíada ${ }^{22}$. Creúsa sale de Troya en llamas, caminando en pos de Eneas, que lleva en hombros a su anciano padre. En la huida, Creúsa se queda atrás y se pierde. Eneas no la volverá a ver, pero sí verá la sombra o visión de Creúsa, que le anuncia algunos sucesos de la misión que Eneas debe cumplir. Se puede considerar, pues, que Creúsa sale de Troya, no se sabe si muere ni consta que muera entre las llamas: los dioses han intervenido de alguna forma, y el destino de Creúsa queda incógnito, salvo el dato de quedar bajo la protección de los dioses (misteriosamente viva o su espíritu, si ha perecido en el camino).

Puede decirse, por tanto, que Lope maneja con cierta libertad el motivo de la fuga de Creúsa, pero no se confunde ni falsea lo narrado en la Eneida:

heu misero coniunx fatone erepta Creusa
substitit, errauitne uia seu lapsa resedit,
ncertum; nec post oculis est reddita nostris

(Eneida, II, 738-740).

et terram Hesperiam uenies, ubi Lydius arua inter opima uirum leni fluit agmine Thybris. illic res laetae regnumque et regia coniunx parta tibi; lacrimas dilectae pelle Creusae. non ego Myrmidonum sedes Dolopumue superbas aspiciam aut Grais seruitum matribus ibo, Dardanis et diuae Veneris nurus; sed me magna deum genetrix his detinet oris (Eneida, II, 781-788).

22 Supongo una errata o lapsus de Sánchez Jiménez por la cercanía de los nombres. Morby trae bien el nombre de la mujer de Eneas. 
Juan de la Cueva, en Áyax Telamón, interpreta, efectivamente, que Creúsa queda bajo el amparo de los dioses, ya que no puede acompañar a Eneas en su destino, pero ni muere ni queda prisionera en la ciudad devastada, a la que regresa de modo misterioso tras perderse en el camino de la fuga:

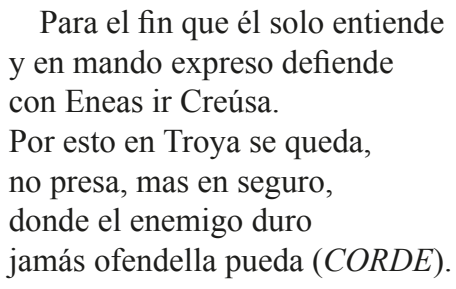

15. ¿Temis o Tetis?

Otro lugar dudoso en la edición de Sánchez Jiménez es la mención de Temis, cuyo oráculo consulta Venus al ver que su hijo Cupido no crece:

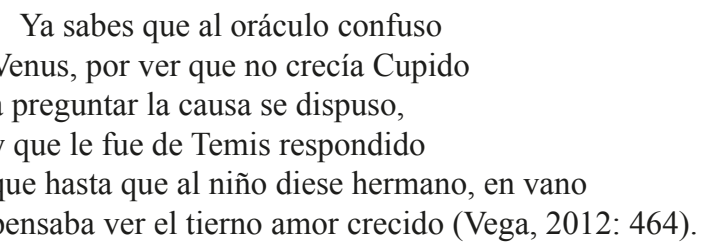

La confusión se produce en la nota que explica a «Tetis, hija de la Tierra, "tuvo un famoso oráculo en Beocia”» («Exposición», n. 680).

La nota cambia el nombre de Temis en Tetis. La «Exposición» citada trae la buena lectura, Temis (no Tetis) «Temis, hija de la Tierra que tuvo un famoso oráculo en Beocia, junto al río Cefiso. Ovid. 1 Met.» (718). Es posible que la confusión del anotador provenga de que la titánide Tetis, divinidad de las aguas, era efectivamente hija de la Tierra y hermana de Temis. Según versiones de los mitos Júpiter tuvo tres mujeres: Metis (hija del Océano y de Tetis, la cual era a su vez hija del Cielo y de la Tierra), Temis (hija del Cielo y la Tierra) y Juno. El oráculo de Temis, según Baltasar Vitoria (Teatro de los dioses de la gentilidad), fue el más antiguo de la gentilidad. Vitoria comenta la respuesta que Temis da a Venus sobre el crecimiento de Cupido, y la necesidad de que Cupido tuviera un compañero (Anteros, el amor correspondido), y lo considera, como todos los oráculos paganos confuso y errado, aduciendo como ilustración el pasaje de Lope que comento («Estas respuestas y otras dieron ocasión a que se llamase 
el oráculo confuso el desta diosa Temis, como lo dijo Lope de Vega...», I, lib. IV, cap. 15).

\section{El CARdo ENTERRAdo}

En una serie de informaciones agrícolas sobre frutales y hortalizas, se compara al cardo con el avariento, porque los dos aprovechan mejor sepultados: «el cardo, bueno enterrado / como el avariento vil, / que aprovecha sepultado» (Vega, 2012: 591). Para Sánchez Jiménez, el texto se refiere a que «Los buenos cardos o cardillos están parcialmente enterrados. Del mismo modo, el avaro solo es bueno cuando se le entierra, pues solo entonces distribuye su riqueza, en el testamento» (n. 921). La comparación es evidente, pero la identificación de la planta y el hecho de estar enterrados los cardos no quedan claros en la nota, que puede conducir a una idea errada del vegetal mencionado.

Tal como ha ilustrado magistralmente Ángel Gómez Moreno (2011), los detalles botánicos desempeñan a menudo papeles muy relevantes en el arte y la literatura, y conviene precisarlos lo mejor posible. En lo que se refiere a los cardos hay muchas especies que los textos áureos mencionan, usando, entre otros términos cardo arrecife, cardo ajongero o carlina, cardo santo o cardo bendito, cardo corredor, cardillo o targarnina, cardo mariano, cardo borriquero... y cien más. Lo que me interesa apuntar aquí es que los «cardos» no se identifican con los «cardillos». Los cardillos o tagarninas («targarnina»: 'Lo mismo que cardillos', Diccionario de autoridades) son una especie silvestre, de menor volumen que los cardos y que no se aporcan o entierran. Es una de las hierbas que el escudero del caballero del Bosque rechaza como dieta de los caballeros andantes: «-Por mi fe, hermano —replicó el del Bosque-, que yo no tengo hecho el estómago a tagarninas, ni a piruétanos, ni a raíces de los montes» (Quijote, II, 13).

Hernán Cortes, en sus Cartas de relación, enumera una lista de verduras de Nueva España a las que da nombres españoles y distingue los cardos de las tagarninas en pasaje que copian luego González de Oviedo y Alonso de Zurita: «Hay todas las maneras de verduras que se hallan, especialmente cebollas, puerros, ajos, mastierzos, berros, borrajas, acederas y cardos y tagarninas» (Hernán Cortés, CORDE).

Uno de los problemas de las identificaciones botánicas es la variedad de la nomenclatura, ya que la misma especie recibe nombres distintos en diversas regiones $^{23}$, o se aplica el mismo a variedades distintas. La cuestión es sumamente complicada, como apunta Álvarez López:

23 El cardillo o targanina, por ejemplo, se llama en distintas regiones de España cadillo, cardetes, cardico de monte, cardico de olla, cardillo blanco, cardillo de comer, cardillo real, cardillón, cardo lechal, cardo manso, cardo mantequero, cardo pavero, cardo santo, cardo triguero, cardo zafranero, lechocino, tagardilla, tagardina, tagarninas burreras, tagarrina, etc. Algunos de estos términos como lechocino o 
El asunto de las compuestas espinosas que de una manera general podemos llamar cardos, es muy complejo. Por una parte se trata de especies muy numerosas, muchas de ellas con hábitos o propiedades semejantes, suficientemente llamativas para ser notadas, pero por lo general también sin rasgos bastantes para que su distinción pudiera ser claramente transmitida de unos autores a otros. No puede extrañarnos por ello que la duda o la vacilación se transparenten muchas veces sobre este tema (1947: 123).

Pero, dejando a un lado estas complicaciones a menudo irresolubles, en cualquier caso, la tagarnina o cardillo (Scolymus hispanicus) no es el cardo a que se refiere el texto de Lope. Se refiere a una variedad cultivada (seguramente el Cynara cardunculus) que ha de sembrarse en abril, que se tapa con tierra para que las pencas queden más tiernas y blancas, porque si les da el sol toman un color verde y se hacen amargas. La práctica sigue vigente en el cultivo actual del cardo en distintas zonas españolas, como Navarra, donde se ha sustituido habitualmente la pared de tierra que cubría al cardo, difícil de hacer y fatigosa, por la técnica de envolver las plantas con papel o plástico.

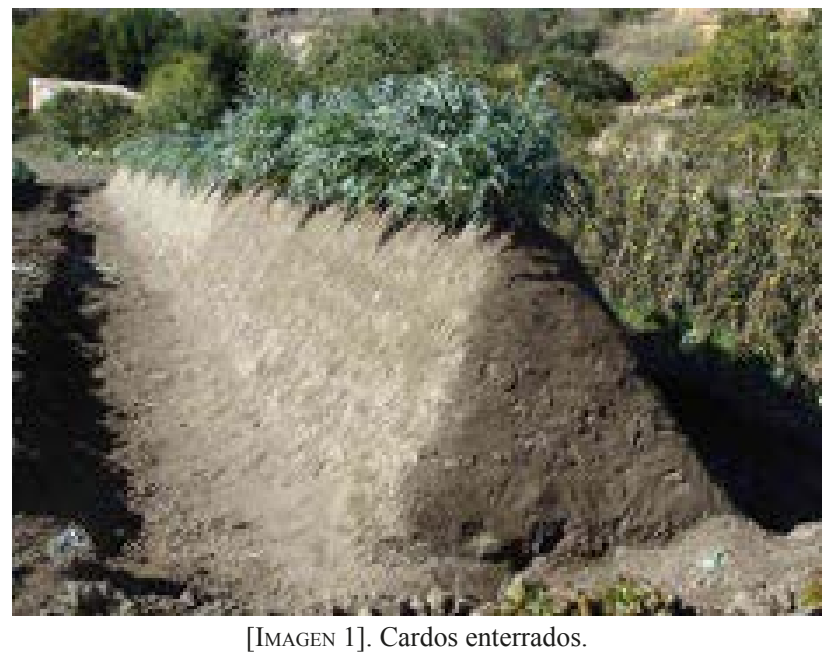

De estos cardos comenta Gabriel de Herrera en su Obra de agricultura, explicando la técnica del entierro de las pencas:

lechacino se aplican a plantas distintas en otras zonas. Es difícil decidir a menudo a qué especie se puede referir exactamente un texto entre tantas variedades mencionan Dioscórides (cirsio, buglosa, hippophesto, silibo, etc.). Laguna en sus comentarios no tiene claras tampoco ciertas diferencias entre cardo (scholymo), alcahofa (cinaria) y otras variedades. 
El sembrar simiente es lo mejor por marzo y principio de abril y el poner dellos sea que pongan por liño en acequia larga por amor del regar donde regarse tienen y vaya una mata puesta de otra un buen tranco por amor del aporcar que la tierra de enmedio se parta para cobrir el cardo, digo la de los entreliños que con la mitad de una parte del medio liño y con la otra mitad dela otra parte se cubra el cardo y por el liño vaya una mata de otra dos pies porque al aporcar vaya una acostada sobre otra $(C O R D E)$.

\section{Los filósofos Cleontino, Cleóbulo (y su muerte) y los Amores de Aristóteles}

En la serie de sabios que a la vez se ocuparon en amores argumenta Anfriso:

Acuérdate del maestro de Platón, que amaba y enseñaba, y que Cleontino tenía su casa llena de mujeres y sus escuelas de dicípulos. No se despeñó estudiando Cleóbulo, ni le estorbó la edad larga la intempestiva muerte (Vega, 2012: 597).

Las notas que ponen los editores a este pasaje no resultan satisfactorias. Morby se limita a consignar: «Cleontino, filósofo. [El maestro de Platón es Sócrates; Cleóbulo, filósofo, usualmente incluido entre los siete sabios de Grecia]» (1975: 390, n. 28). Y Sánchez Jiménez, que de nuevo ve una equivocación en Lope, no ayuda mucho más:

Cleontino: «filósofo» («Exposicion»). Pese a esta parquísima definición, creemos que Lope se equivoca, y que ha confundido el nombre de Gorgias (Gorgias Leontinus, o abreviado, G. Leontinus). Obviamente el Fénix encontró estas noticias sobre los filósofos y el amor en alguna poliantea.

Cleóbulo fue uno de los Siete Sabios de Grecia, conocido no solo por su filosofía, sino también por su belleza (597, nn. 948 y 949).

En realidad Lope no se equivoca: simplemente maneja alguna fuente en la que el nombre del filósofo es exactamente Cleontino, variación onomástica del filósofo que apunta, sin dar en el blanco, Sánchez Jiménez. Por el detalle de la cercanía de Cleóbulo y la referencia a la muerte intempestiva de este (que se «despeñó»), junto con otros detalles (que no se siguen al pie de la letra) la fuente de Lope parece ser el Libro áureo del emperador Marco Aurelio, del obispo Guevara, donde viene el nombre de Gorgias Cleontino en la forma que usa Lope:

Cleóbolo el curiano al cabo de ochenta años de su edad y cuarenta y cinco que leía filosofía, escalando la casa de una su vecina, cayó y murió de una escalera. [...] Anacarses [...] tanto amor tuvo con una amiga suya tebana que le enseñó cuanto sabía y cuando él estaba malo en la cama ella leía por él en la academia [...] Gor- 
gias Cleontino, natural de Sicilia más concubinas tenía en su casa que libros en la academia [...] (1593: f. 171r).

«Cleontino» es la forma de la edición del Libro áureo de Amberes, 1539; de la de Venecia, Gabriel Giolito de Ferrariis, 1553 (f. 185r), etc.

En todo caso, el texto de Guevara explica la intempestiva muerte de Cleóbolo a edad tan avanzada como ochenta años por escalar la casa de una vecina, y la forma Cleontino de Lope, que no se equivoca, sino que usa una forma conocida del nombre del filósofo.

Otro de los filósofos mencionados es Aristóteles, «desterrado por adorar una mujer» (Vega, 2012: 598), que Sánchez Jiménez identifica como la meretriz Hermia, remitiendo a Ravisio Textor.

Conviene añadir unas pocas palabras. El de los amoríos de Aristóteles es un motivo clásico, muy extendido en la Edad Media, y contaminado de dos variantes. La primera — que es la que se alude en la Arcadia a juzgar por otro texto de la Dorotea - es la de Hermias, en efecto. El pasaje de Ravisio Textor, en la nómina de meretrices famosas, es este:

Hermia fuit meretrix, cui prae nimio amore sacra fecit Aristoteles, eiusque laudibus hymnos dicavit unde ab Eurimedonte seu Demophilo accusatus, relictis Athenis (ubi XXX. annos docuerat) Chalcidem se recepit. Autor Origenes.

Hermias era en realidad un hombre, tirano de Atarne, una de cuyas concubinas se dice — según algunas versiones de los hechos - que fue mujer de Aristóteles. Esto refiere Diógenes Laercio en su Vida de Aristóteles:

Pasó después a estar con el eunuco Hermias, que era tirano de los atarnenses y según algunos su bardaje, bien que otros afirman que tenía afinidad con él, habiéndole dado en mujer a su hija o sobrina, como dice Demetrio de Magnesia [...] el cual añade que Hermias había sido esclavo de Eubulo [...] Aristipo, en el libro I de Las delicias antiguas, dice que Aristóteles amó una concubina de Hermias, y que habiéndola tomado por mujer y por el gran gozo que tuvo le ofreció sacrificios, como los atenienses a Ceres Eleusina, y a Hermias le compuso el himno que escribiremos abajo (1991: 115).

Cuenta también que fue acusado de impiedad por Eurimedonte o Demófilo, según diversos testimonios, a causa del himno compuesto a Hermias, y desterrado por ello.

El padre Feijoo sigue la versión de Laercio y sabe bien que Hermias era el tirano de Atarne, y no mujer: «no faltaron quienes diesen los más infames y sucios colores al grande amor que profesó a Aristóteles Hermias, tirano de Atarne; no 
obstante que todos aseguran que este tirano era eunuco» (Teatro crítico, IV, discurso 7, párrafo 19).

Estos motivos se confunden en la tradición posterior. En la Dorotea (Vega, 1980: 242) Lope vuelve a recordar el hecho llamando a la dama de Aristóteles Hermia, y aludiendo al destierro del filósofo:

Onfalia rindió a Hércules, Briseida a Aquiles; pues en llegando a sabios, Aristóteles adoraba a Hermia y le compuso himnos, como usaban los griegos a los dioses, tanto que acusado de Demófilo y Eurimedonte, se desterró de Atenas $^{24}$ (acto 3, escena 2).

Y otra vez en un soneto de las Rimas humanas y divinas del licenciado Tomé de Burguillos:

Vuesa merced se tiemple en darle penas, señor Amor, a un hombre de mi fama, que si quiso Aristóteles su dama también le desterraron los de Atenas...

La segunda variante de los amores de Aristóteles, que no hubiera podido utilizar Polinesta en sus ejemplos del estudio vencedor del vicio, y que por tanto no es pertinente en el pasaje de la Arcadia, es la de Filis, bella cortesana que para vengarse de los desprecios del filósofo lo seduce y obliga a llevarla en su lomo como si fuera una caballería, con freno y cincha, tema que se refleja en textos y grabados durante los siglos posteriores.

\section{LAS FUentes de BeOcia}

Anfriso, llevado por Polinesta a su estudio, «como si hubiera bebido en las famosas fuentes de Beocia que la una da la memoria y otra la quita, así estaba divertido y suspenso» (Vega, 2012: 616).

Sánchez Jiménez anota que,

En Beocia existía una fuente dedicada a la madre de las Musas y diosa de la memoria Mnemosine. También había una de este nombre en el Hades, que daba la memoria a quienes bebían de ella, al contrario que les ocurría a los que bebían del Lete. No hemos podido averiguar de dónde extrajo Lope esta noticia (n. 999).

\footnotetext{
24 En su nota de la Dorotea, Morby remite a Diógenes Laercio y señala que, para Lope, Hermia es mujer, como en la Arcadia. Como apunta Morby, el dato de Lope debe de provenir del citado pasaje de Ravisio Textor, aunque esta versión podría haberse transmitido de otras fuentes.
} 
El motivo del texto no tiene relación con las Musas, el Hades o el Leteo, sino con una de las innumerables fuentes maravillosas que son componente ineludible de las misceláneas y silvas, y que a menudo se estructuran como parejas antitéticas (las aguas de una provocan fertilidad, las de otra esterilidad; las ovejas que beben de una se ponen blancas, las que beben de otras negras, etc.).

Probablemente Lope recuerda aquí el pasaje de Pero Mexía, que dedica un capítulo entero, el XXXI de la segunda parte de su libro, a lagos y fuentes maravillosos: «De otras dos fuentes en Boecia escribe san Isidoro y estos otros autores alegados: la una quita totalmente la memoria y la otra que la ayuda y hace que todos se acuerden» (1989: I, 729). Pero pudiera recordar a san Isidoro mismo (Etimologías, XIII, 3: «In Boeotia duo fontes: alter memoriam, alter oblivionem adfert»). O bien a Plinio (1999: XXXI, 2): «En Beocia, junto al río Orcomeno, hay dos fuentes dedicadas al dios Trofonio, de las cuales la una da la memoria y la otra olvido, y de aquí las dieron el nombre» (1.031). Covarrubias en el suplemento del Tesoro también las recuerda, s.v. «fuente»: 'En Boecia hay otras dos, la una quita totalmente la memoria y la otra la aumenta'.

\section{FINAL}

Lope, sin duda, muestra una inclinación, a menudo ingenua, a exhibir conocimientos y erudiciones, pero también explota directamente la atracción indudable que las curiosidades tienen para el público de todos los tiempos, desde los lectores de las Historias curiosas de Claudio Eliano, hasta — más cerca de Lope- los aficionados a las silvas de varia lección, como la de Pero Mexía o el Jardín de flores curiosas de Torquemada. En la Arcadia integra estas variaciones de los materiales pertinentes. Buscar una justificación — como la supuesta inquietud pedagógica y «seria» que propone Morby - o señalar con dedo acusatorio la «acumulación desorganizada» de estos componentes es igualmente errado, a mi juicio, lo mismo que esforzarse en rastrear una unidad coherente - según los criterios modernos-.

Pero, independientemente de la valoración que se haga de estos elementos, es obvio que plantean al lector moderno una serie de dificultades. Proporcionarle un aparato de notas aclaratorias se hace indispensable. La complejidad de las referencias, fuentes, alusiones, conceptos, ideas sobre el mundo y la cultura, creencias zoológicas, botánicas y lapidarias, emblemas y mitologías... convierten a textos como la Arcadia en un laberinto de innumerables pliegues, y a la tarea de anotarlos en una grande, aunque eutrapélica fatiga. Y siempre hay motivos que encubren un sentido oculto, disimulado u olvidado para el lector de un tiempo que ya no maneja los mismos modelos culturales. Pero, sin la comprensión de esos motivos una parte esencial de obras como la Arcadia, se pierde. Para contribuir en modesta medida a esa comprensión están redactadas las notas precedentes. 


\section{BIBLIOGRAFÍA}

Alejos Morán, Asunción (1995). «Jeroglíficos marianos en el Siglo cuarto de la conquista de Valencia». En Sagrario López Poza (ed.), Literatura emblemática hispánica. Actas, I Simposio Internacional de Literatura Emblemática Hispánica. La Coruña: Universidad de la Coruña, pp. 277-292.

Álvarez López, Enrique (1974). «Comentarios históricos y botánicos con motivo de un "Glosario" hispano-musulmán de los siglos XI al XII». Anales del Jardín Botánico de Madrid, 7, pp. 5-175.

Amiano Marcelino (1967). Rerum gestarum. Viktor Gardthausen (ed.). Stutgardiae: Teubner. Aquilecchia, Giovanni (1978). «Il passero solitario di Leopardi e un sonetto del Molza». Italian Studies, 33, pp. 77-82.

Arellano, Ignacio (1990). «Piedras y pájaros: ilustración extravagante a un pasaje del Médico de su honra de Calderón». Bulletin Hispanique. Homenaje a M. Chevalier, 92: 1, pp. 59-69.

Arellano, Ignacio (2011). Repertorio de motivos de los autos sacramentales de Calderón. Pamplona: Servicio de Publicaciones de la Universidad de Navarra $<$ https://dadun. unav.edu/handle/10171/20441> [Consulta: 16/12/2020].

Arellano, Ignacio (2015). «La erudita bufonería de La pícara Justina. Algunas notas». Revista de História da Sociedade e da Cultura, 15, pp. 33-52.

Arellano, Ignacio (2016). «Empresa de la envidia: los ojos del búho en Saavedra Fajardo». Criticón, 12, pp. 217-222.

Avalle Arce, Juan Bautista (1959). La novela pastoril española. Madrid: Revista de Occidente.

Boethius, Anicius Manlius (2013). De institutione música. Ljubljana: Narodna in univerzitetna knjiznica.

BorJa, Juan de (1680 [1581]). Empresas morales. Bruselas: Foppens.

Calderón de la Barca, Pedro (1999). A María el corazón. Ignacio Arellano et alii (eds.). Pamplona / Kassel: Universidad de Navarra / Reichenberger.

Calderón de la Barca, Pedro (2005). El verdadero dios Pan. Fausta Antonucci (ed.). Pamplona / Kassel: Universidad de Navarra / Reichenberger.

Calvo Pinto, Agustín (1754). Silva venatoria. Madrid: Herederos de don Agustín de Gordejuela.

CAMERARIo, Ioachimo (1593). Symbolorum et emblematum ex volatilibus et insectis desumtorum. Nuremberg: Johannis Hofmanni \& Huberti Camoxii.

CASE, John (1588). Apologia musices tam vocalis quam instrumentalis et mixtae. Oxford: Josephus Barnesius.

Castriota, Constantino (1522). Il sapere util'e delettevole. Napoli: Cilio Alifano.

Cervantes, Miguel de (1947-1949). Don Quijote de la Mancha. Francisco Rodríguez Marín (ed.). Madrid: Atlas.

Conde Parrado, Pedro y Javier García Rodríguez (2002). «Ravisio Textor entre Cervantes y Lope de Vega: una hipótesis de interpretación y una coda teórica». Tonos, 4 $<$ https://digitum.um.es/digitum/handle/10201/50930> [Consulta: 16/12/2020].

ConTI, Natale (1611). Natalis Comitis Mythologiae, siue Explicationum fabularum libri decem. Genevae: Stephanum Gamonetum. 
CORDE. Corpus diacrónico del español <http://www.rae.es> [Consulta: 16/12/2020]. Covarrubias Horozco, Sebastián (1610). Emblemas morales. Madrid: Luis Sánchez.

Covarrubias Horozco, Sebastián (2006). Tesoro de la Lengua castellana o española. Ignacio Arellano y Rafael Zafra (eds.). Pamplona: Universidad de Navarra / Iberoamericana / Vervuert / Real Academia Española / Centro para la Edición de Clásicos Españoles. Cubillo de Aragón, Álvaro (1654). El enano de las musas. Madrid: María de Quiñones.

Diodoro Sículo. Biblioteca histórica, II <http://www.anarkasis.net/Diodoro-de-Sicilia/ libro2.htm> [Consulta: 16/12/2020].

Egido, Aurora (1990). «Lope de Vega, Ravisio Textor y la creación del Mundo como obra de arte». Fronteras de la poesía en el Barroco. Barcelona: Crítica, pp. 198-215.

Eliano, Claudio (1984). Historia de los animales, IX-XVI. José María Díaz-Regañon López (ed.). Madrid: Gredos.

Eliano, Claudio (2006). Historias curiosas. Madrid: Gredos.

Eliano, Claudio (2008). Historia de los animales, I-VIII. José María Díaz-Regañon López (ed.). Madrid: Gredos.

FerRer de VALDECEBro, Andrés (1696). Gobierno general, moral y político hallado en las aves más generosas y nobles. Barcelona: Cormellas.

Gómez Moreno, Ángel (2011). «La flora entre los primitivos y Cranach. De Razón de amor a Cervantes: paisaje, exégesis y poética». Edad de Oro, 30, pp. 127-166.

Góngora, Luis de (1994). Soledades. Robert Jammes (ed.). Madrid: Castalia.

Góngora, Luis de (1998). Romances. Antonio Carreira (ed.). Barcelona: Quaderns Crema.

GonzÁlez Barrera, Julián (2007). «Lope de Vega y los "librotes" de lugares comunes: su lectura particular de Ravisio Téxtor». Anuario Lope de Vega, 13, pp. 52-71.

Guevara, Antonio de (1593). Libro áureo de Marco Aurelio. Amberes: Juan Steelsio.

Horozco y Covarrubias, Juan de (1589). Emblemas morales. Segovia: Juan de la Cuesta.

Isidoro, san (1993). Etimologías. Manuel A. Marcos Casquero y José Oroz Reta (eds.). Madrid: Biblioteca de Autores Cristianos.

JAMESON, Ann K. (1937). «The Sources of Lope de Vega's Erudition». Hispanic Review, 5, pp. 124-139.

Laercio, Diógenes (1991). Vidas de los filósofos más ilustres. Ciudad de México: Porrúa.

López Baralt, Luce (1984). «Para la génesis del "pájaro solitario” de San Juan de la Cruz». Romance Philology, 37, pp. 409-424.

LuCANo, Marco Anneo (1984). Farsalia <https://kupdf.net/download/lucano-marco-anneola-farsalia-bilinge_5a04077fe2b6f5a32305de4b_pdf $>$ [Consulta: 16/12/2020].

Martínez de Espinar, Alonso (1946). Arte de ballestería y montería. Madrid: Ediciones y Publicaciones Españolas.

Mexía, Pero (1989-1990). Silva de varia lección. Antonio Castro (ed.). Madrid: Cátedra.

Morby, Edwin (1967). «Franz Titelmans in Lope’s Arcadia». Modern Language Notes, 82, pp. 185-197.

Morby, Edwin (ed.) (1975). Lope de Vega, La Arcadia. Madrid: Castalia.

Morby, Edwin (1968). «Constantino Castriota in the Arcadia». En Walter Poesse (ed.), Homage to John M. Hill. Valencia: Indiana University, pp. 201-215.

Moya del Baño, Francisca (1969). Estudio mitográfico de las Heroidas de Ovidio (IV, V, VII, X, XVIII, XIX). Murcia: Universidad de Murcia. 
Osuna, Rafael (1968). «El Dictionarium de Stephanus y la Arcadia de Lope». Bulletin of Hispanic Studies, 45, pp. 265-269.

Osuna, Rafael (1996). Polifemo y el tema de la abundancia natural en Lope de Vega y su tiempo. Kassel: Reichenberger.

Pellicer, José (1630). Lecciones solemnes a las obras de don Luis de Góngora. Madrid: Imprenta del Reino.

Peñasco González, Sandra (2015). Edición filológica y estudio de Emblemas morales de Sebastián de Covarrubias Orozco (1610). Sagrario López Poza (dir.) [tesis doctoral]. A Coruña: Universidade da Coruña $<$ https://core.ac.uk/download/pdf/95054355.pdf $>$ [Consulta: 16/12/2020].

Perea Rodríguez, Óscar (2010). «Juego de los propósitos». En Gran Enciclopedia Cervantina. Madrid: Castalia, t. 7, pp. 6.514-6.516.

Plinio (1999). Historia natural. Francisco Hernández y Jerónimo de Huerta (trad.). Madrid: Visor.

Plutarco (1986). Moralia. Harold Cherniss y William C. Hembold (ed.). Cambridge / London: Harvard University Press / W. Heinemann.

Quevedo, Francisco de (2020). El Parnaso español. Ignacio Arellano (ed.). Madrid: Real Academia Española / Espasa.

Ravisius TeXtor, Iohannes (1593). Officinae Ioannis Ravissi Textoris epitome. Lugduni: Antonium Gryphium.

Real Academia Española (1990). Diccionario de autoridades. Madrid: Gredos [ed. facsímil, 3 t.].

RIPA, Cesare (1987). Iconología. Juan y Yago Barja (trads.). Madrid: Akal.

Rodríguez MARÍn, Francisco (2007 [1926]). Más de 21.000 refranes castellanos no contenidos en la copiosa colección del maestro Gonzalo Correas. Madrid: Atlas.

Salazar y Torres, Agustín (1694). Cítara de Apolo. Madrid: Antonio González.

Salcedo Coronel, José (1636). Soledades de don Luis de Góngora comentadas. Madrid: Imprenta Real.

Sebastián, Santiago (1981). «El tema del Triunfo de César en la decoración del Renacimiento español». Cuadernos de trabajos de la Escuela Española de Arqueología e Historia en Roma, 5, pp. 241-246.

Solino, Cayo Julio (1573). De las cosas maravillosas del mundo. Cristóbal de las Casas (trad.). Sevilla: García Escribano.

Sото, Hernando de (1983). Emblemas moralizadas. Carmen Bravo Villasante (ed.). Madrid: Fundación Universitaria Española.

SuÁrez de FigueroA, Cristóbal (1629). Plaza universal de todas ciencias y artes. Enrique Suárez Figaredo (ed.). Perpiñán: Luis Roure Librero.

Suetonio (2006). Vida de los Césares. Vicene Picón (ed.). Madrid: Cátedra.

Torquemada, Antonio de (2012). Jardín de flores curiosas. Enrique Suárez Figaredo (ed.). Lemir, $16<\mathrm{http} / /$ parnaseo.uv.es/Lemir/Revista/Revista16/Textos/07 Jardin Flores Torquemada.pdf $>$ [Consulta: 16/12/2020].

Trueblood, Alan (1958). «The Officina of Ravisius Textor in Lope de Vega's Dorotea». Hispanic Review, 26, pp. 135-141.

Valeriano, Piero (1562). Hieroglyphica sive de sacris aegyptiorum, aliarum Gentium. Basileam: Guarinum. 
VEGA, Lope de (1604). «Vida y muerte del rey Bamba». En Las comedias del famoso poeta Lope de Vega Carpio. Zaragoza: Angelo Tavanno.

Vega, Lope de (1975). La Arcadia. Edwin Morby (ed.). Madrid: Castalia.

VeGA, Lope de (1980). La Dorotea. Edwin Morby (ed.). Madrid: Castalia.

Vega, Lope de (2012). La Arcadia. Antonio Sánchez Jiménez (ed.). Madrid: Cátedra.

VEGA, Lope de (2016). El peregrino en su patria. Julián González Barrera (ed.). Madrid: Cátedra.

Vega, Lope de (2019). Rimas humanas y divinas del licenciado Tomé de Burguillos. Ignacio Arellano (ed.). Madrid / Frankfurt am Main: Iberoamericana / Vervuert.

VIRUÉs, Cristóbal de (1609). La gran Semíramis. Teresa Ferrer Valls (ed.). Biblioteca Virtual Miguel de Cervantes <http://www.cervantesvirtual.com/nd/ark:/59851/bmc67089> [Consulta: 16/12/2020].

Vitoria, Baltasar de (1702). Teatro de los dioses de la Gentilidad. Barcelona: Juan Pablo Martí.

Vosters, Simon (1962). «Lope de Vega y Titelmans: cómo el Fénix se representaba el Universo». Revista de Literatura, 21-22, pp. 5-33.

Vosters, Simon (1975). «Lope de Vega y Juan Ravisio Téxtor. Nuevos datos». Iberorromania, 2, pp. 69-101.

Recibido: $17 / 12 / 2020$

Aceptado: 11/02/2021 


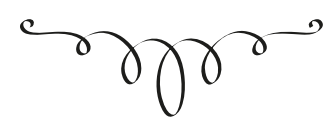

\section{Notas de Varia lección a la ARCADIA De Lope de Vega}

Resumen: El artículo aborda una serie de motivos y referencias eruditas y curiosas de la Arcadia de Lope de Vega, indagando en su sentido, fuentes posibles y función poética. Frente a diversas interpretaciones que consideran estos elementos materiales de erudición postiza, se defiende la utilización por parte de Lope como componentes curiosos capaces de atraer la atención del lector, y se muestra el dominio de los repertorios diversos, apuntando fuentes posibles que explican algunas variantes menos difundidas de algunos de estos motivos eruditos y curiosos.

PALABRAS ClaVE: Anotación de textos, novela pastoril, Lope de Vega, erudición, curiosidades.

\section{Notes From VARIOUS LESSONS TO LoPE DE VeGA's ARCADIA}

ABSTRACT: The article examines a series of erudite and curious motifs and references in Lope de Vega's Arcadia, investigating its meaning, possible source and poetic function. Against various interpretations that consider these elements as examples of false erudition, this article defends the use by Lope as curious components capable of attracting the reader's attention; also shows the knowledge that Lope has of the diverse repertoires, pointing out possible emblematic, classical, poetic, or natural history sources that explain, in a more complex and precise way, some variants from some of these curious motifs.

KEYwords: Text annotation, pastoral novel, Lope de Vega, erudition, curiosities. 